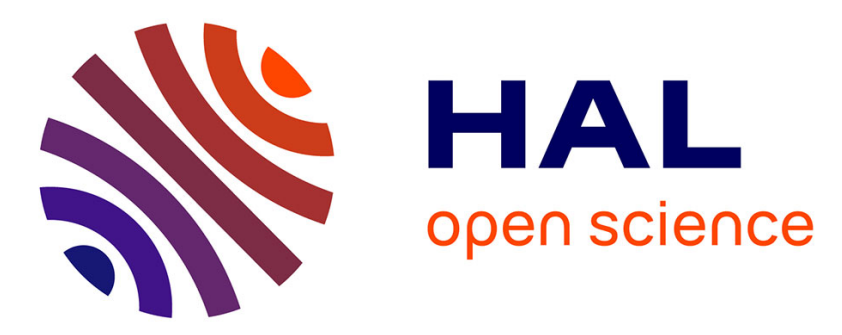

\title{
Evolution of magma conduits during the 1998-2000 eruptions of Piton de la Fournaise volcano, Réunion Island
}

Yo Fukushima, Valérie Cayol, Durand Philippe, Massonnet Didier

\section{- To cite this version:}

Yo Fukushima, Valérie Cayol, Durand Philippe, Massonnet Didier. Evolution of magma conduits during the 1998-2000 eruptions of Piton de la Fournaise volcano, Réunion Island. Journal of Geophysical Research: Solid Earth, 2010, pp.B10204. 10.1029/2009JB007023,2010 . hal-00576879

\section{HAL Id: hal-00576879 \\ https://hal.science/hal-00576879}

Submitted on 15 Mar 2011

HAL is a multi-disciplinary open access archive for the deposit and dissemination of scientific research documents, whether they are published or not. The documents may come from teaching and research institutions in France or abroad, or from public or private research centers.
L'archive ouverte pluridisciplinaire HAL, est destinée au dépôt et à la diffusion de documents scientifiques de niveau recherche, publiés ou non, émanant des établissements d'enseignement et de recherche français ou étrangers, des laboratoires publics ou privés. 


\title{
Evolution of magma conduits during the 1998-2000 eruptions of Piton de la Fournaise volcano, Réunion Island
}

\author{
Y. Fukushima, ${ }^{1}$ V. Cayol, ${ }^{2}$ P. Durand, ${ }^{3}$ and D. Massonnet $^{3}$
}

\begin{abstract}
At basaltic volcanoes, magma is transported to the surface through dikes (magma-filled fractures), but the evolution of these dikes as eruptions proceed is rarely documented. In March 1998, after five and a half years of quiescence, Piton de la Fournaise volcano (Réunion Island) entered into a new eruptive phase characterized by intense eruptive activity. Co-eruptive displacements recorded by interferometric synthetic aperture radar (InSAR) for the first five eruptions of the cycle are analyzed using 3-D boundary element models combined with a Monte Carlo inversion method. We show that the eruptions are associated with the emplacement of lateral dikes rooted at depths of less than about $1000 \mathrm{~m}$, except for the first March 1998 event where an additional deeper source is required. The dikes are located above pre-eruptive seismic swarms. This is consistent with nearly-isotropic stress due to repeated dike intrusions and low confining pressure enhanced by the presence of pores in the shallowest $1000 \mathrm{~m}$ of the edifice. The volumes of the modeled dikes represent $17 \%$ of the volume of emitted lava, showing that exogenous growth plays a major role in building the volcano. By taking into account the pre-eruptive seismicity and tilt data together with the results of InSAR data modeling, we find that dikes first propagate vertically from a source region below sea level before being injected laterally at shallow depth. This behavior is consistent with the presence of levels of neutral buoyancy at shallow depth in the edifice.
\end{abstract}

\section{Introduction}

At basaltic volcanoes, eruptions often start from tensile failure of a relatively shallow magma reservoir and the injection of magma into dikes [Robson and Barr, 1964]. When the dike reaches the ground surface, magma erupts, generally creating fire fountains. The activity then gradually shifts to a circular vent from which the eruption may continue for days, weeks, months or even years [Bruce and Huppert, 1989, 1990; Ida, 1992]. The path taken by magma as eruptions proceed can only be determined indirectly from the interpretation of continuous ground displacements [e.g. Owen et al., 2000; Peltier et al., 2007], the observation of micro-earthquakes preceding eruptions [e.g. Klein et al., 1987], or field observations of eroded volcanoes [e.g. Walker, 1986]. Unraveling this problem is essential to improving our ability to forecast eruptions and to assessing the the factors involved in the evolution of volcanic edifices.

Dikes, after their emplacement, solidify in the shallower portions of the volcanic edifice, producing permanent deformation that can be recorded by temporally discontinuous measurement techniques such as interferometric synthetic aperture radar (InSAR) and GPS campaign surveys. InSAR measures ground displacements over areas of thousands of square kilometers, with high spatial resolution and centimeter-level precision, enabling the detailed geometry of newly solidified dikes to be constrained [e.g. Cervelli et al., 2002; Froger et al., 2004; Fukushima et al., 2005; Jónsson

\footnotetext{
${ }^{1}$ Disaster Prevention Research Institute, Kyoto University, Uji, Kyoto, Japan. Also at Department of Geophysics, Stanford University, Stanford, California.

${ }^{2}$ Laboratoire Magmas et Volcans, Univ. B. Pascal, CNRS UMR 6524, Clermont-Ferrand, France.

${ }^{3}$ Centre National d'Etudes Spatiales, Toulouse, France.
}

Copyright 2010 by the American Geophysical Union. $0148-0227 / 10 / \$ 9.00$ et al., 1999]. Ground displacements are measured with a typical repeat time of a month, thus InSAR is complementary to continuous ground-based geodetic measurements such as tilt or GPS [e.g. Aoki et al., 1999; Cervelli et al., 2002; Battaglia and Bachèlery, 2003; Peltier et al., 2005], and to seismic measurements that can be used to track the injection of magma during eruption [e.g. Battaglia et al., 2005; Klein et al., 1987; Ryan, 1987a].

Piton de la Fournaise $\left(\left(21.244^{\circ} \mathrm{S}, 55.714^{\circ} \mathrm{E}\right)\right.$, Figure 1$)$, a basaltic shield volcano located on Réunion Island, is one of the most active volcanoes on Earth. In March 1998 an eruptive cycle started after five and a half years of unusual quiescence (see Peltier et al. [2009] for a summary). Since then, an average of 2.5 eruptions per year have occurred, including a voluminous eruption in April 2007 which culminated in a 330 meter deep caldera collapse [Michon et al., 2007a]. This eruption might have ended this 10 year cycle. Most eruptions occur in the Enclos Fouqué caldera, an $8 \mathrm{~km} \times 12 \mathrm{~km}$ U-shaped depression in which a $2600 \mathrm{~m}$ high summit cone is located. The eruptive activity in the recent 1998-2007 period is characterized by fissure eruptions along two fracture zones having $\mathrm{N} 25^{\circ}-30^{\circ} \mathrm{E}$ and $\mathrm{N} 120^{\circ} \mathrm{E}$ trends [Michon et al., 2007b].

The volcano is very extensively monitored. The Observatoire Volcanologique du Piton de la Fournaise (OVPF) operated eight continuous tiltmeters, five extensometers and 1920 seismometers between 1998 and 2000. The central area of the volcano is covered by recent lava flows, which favor the use of the InSAR technique, as this technique requires stable characteristics of the ground surface. The intense volcanic activity, together with the extensive monitoring, provide an excellent opportunity to study magma transport associated with fissure eruptions on this basaltic volcano.

Ground displacements are a linear function of the slip, or opening distribution, and a nonlinear function of the source (fracture) geometry. Therefore, the usual strategy for determining dike opening is to first determine the geometry and constant opening for a rectangular dike located in a homogeneous half space, and then to apply linear inversion techniques in order to determine the opening distribution of 


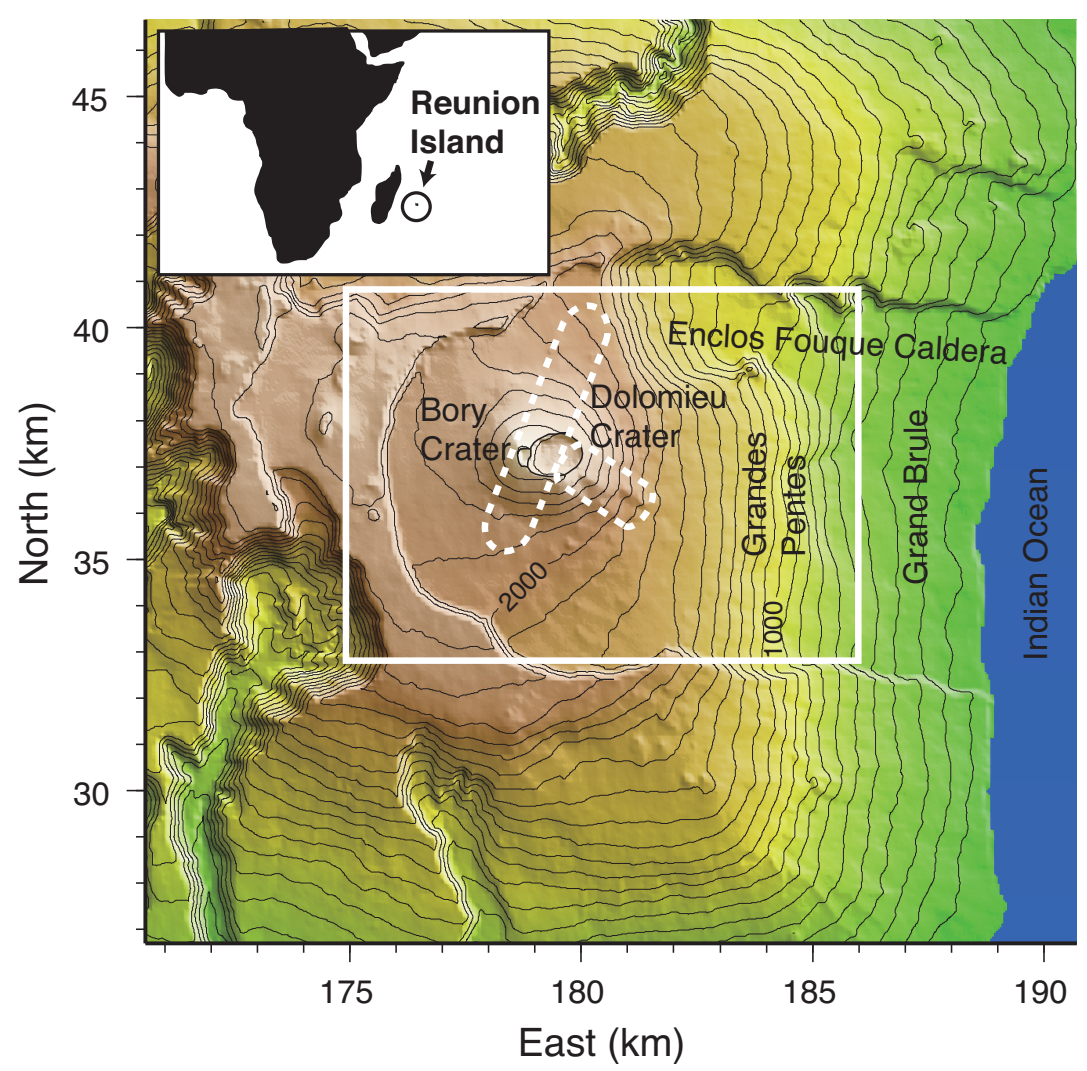

Figure 1. Location of Réunion Island and geological features of Piton de la Fournaise volcano. The geographical coordinates of the summit are approximately $\left(21.244^{\circ} \mathrm{S}, 55.714^{\circ} \mathrm{E}\right)$. Areas encircled with broken curves show $\mathrm{N} 25^{\circ}-30^{\circ} \mathrm{E}$ and $\mathrm{N} 120^{\circ} \mathrm{E}$ trends, along which most of the eruptive fissures appeared in the 1998-2007 eruptive cycle. Rectangle covers the areas shown in Figures 6 - 10. Contours are drawn every $100 \mathrm{~m}$. Coordinates are given in kilometers and correspond to Gauss-Laborde Réunion coordinates.

the previously determined dike [e.g. Amelung et al., 2000; Aoki et al., 1999]. However, the fracture geometry is generally not independent of the opening distribution. Moreover, it is physically more appropriate to impose stresses rather than displacements [Zeller and Pollard, 1992]. Here, we use a boundary element method that takes into account a realistic topography. We assume that dikes have a quadrangular shape with nonuniform opening and shear dislocation distribution resulting from constant pressures (normal stresses) and null shear stresses imposed on the dike surfaces.

In this study, detailed characteristics of the dike-forming intrusions associated with the first five eruptions of the 1998 eruptive cycle are determined using the interferograms computed from SAR images recorded by the Canadian satellite RADARSAT-1. A method that combines a boundary element method and a Monte-Carlo and Bayesian inversion algorithm [Fukushima et al., 2005] is used to constrain and appraise the models. The results are interpreted together with pre-eruptive seismicity and tilt data, providing constraints on magma propagation both before and during eruption.

\section{Data}

Co-eruptive displacements associated with the first five eruptions of Piton de la Fournaise volcano since 1998 were mapped by 18 interferograms, computed from SAR images acquired by the RADARSAT-1 satellite, among which 10 were selected for this study (Table 1). The selection criteria were based on the altitude of ambiguity, which is an indicator of the relative sensitivity of interferometric phases to topography, and also of the spatial baseline phase decorrelation [e.g. Hanssen, 2001; Massonnet and Feigl, 1998]. For subtracting topographic phases, a $100 \mathrm{~m} \times 100 \mathrm{~m}$ digital elevation model (DEM) provided by the French Institut
Géographique National was oversampled to $20 \mathrm{~m} \times 20 \mathrm{~m}$ and used. The accuracy of this DEM is about two meters, which would produce no more than $2 \mathrm{~mm}$ of displacement artifact due to DEM errors for our interferometric pairs.

For two of the eruptions, images were acquired from more than two line-of-sight (LOS) directions, providing good constraints on the displacement field. The interferograms, shown below in section 4, indicate that the Piton de la Fournaise dike intrusions cause complex displacement patterns. We assume that the observed displacements are solely caused by dike intrusions. This assumption seems reasonable because interferometric signals are localized around the eruptive fissures so that any displacements due to magma reservoirs, if any, are much smaller, and because more than two interferograms (processed by using SAR data acquired on different dates) obtained for the same eruption show practically identical displacement patterns within the noise level of a few centimeters.

We unwrapped the interferometric phases using the SNAPHU software [Chen and Zebker, 2000]. When displacement gradients are large, fringes are narrow and normal application of the software leads to unsatisfactory results. To overcome this problem, an iterative unwrapping procedure based on SNAPHU was used [Fukushima et al., 2005]. Interferograms of all the eruptions were successfully unwrapped except for that of the July 1999 eruption, which was of poor quality and was therefore unwrapped manually.

\section{Methodology}

To determine the characteristics of the dikes responsible for the InSAR displacements, we used a method that 
Table 1. Interferograms used in this study

\begin{tabular}{cccccc}
\hline Eruption & Orbit* & $\begin{array}{c}\text { Period } \\
(\text { DD.MM.YY) }\end{array}$ & $\begin{array}{c}\text { Line-of-Sight Vector } \\
\text { [East, North, Up] }\end{array}$ & $\begin{array}{c}\text { Incidence } \\
\text { Angle }\left({ }^{\circ}\right)\end{array}$ & $\begin{array}{c}\text { Altitude of } \\
\text { Ambiguity }(\mathrm{m})\end{array}$ \\
\hline March 1998 & D & $30.04 .97-30.07 .98$ & {$[0.70,-0.19,0.69]$} & 47.1 & 348.0 \\
July 1999 & D & $01.04 .98-11.09 .99$ & {$[0.70,-0.19,0.69]$} & 46.8 & 40.1 \\
Sept. 1999 & D & $11.09 .99-16.12 .99$ & {$[0.70,-0.19,0.69]$} & 46.7 & -162.6 \\
Feb. 2000 & A & $07.02 .00-13.05 .00$ & {$[-0.63,-0.17,0.76]$} & 40.7 & -272.9 \\
& A & $14.12 .99-19.03 .00$ & {$[-0.69,-0.19,0.70]$} & 45.7 & -130.4 \\
& D & $22.10 .99-25.05 .00$ & {$[0.64,-0.17,0.75]$} & 41.8 & -88.0 \\
June 2000 & D & $16.12 .99-01.06 .00$ & {$[0.70,-0.19,0.69]$} & 46.8 & 494.1 \\
& A & $13.05 .00-30.06 .00$ & {$[-0.63,-0.17,0.76]$} & 40.7 & -190.4 \\
& A & $19.03 .00-03.09 .00$ & {$[-0.69,-0.19,0.70]$} & 45.8 & -55.2 \\
& D & $08.05 .00-25.06 .00$ & {$[0.70,-0.19,0.69]$} & 46.6 & 53.8 \\
\hline *A:
\end{tabular}

combines a mixed boundary element method (BEM) and a Monte Carlo inversion algorithm [Fukushima et al., 2005]. The mixed BEM [Cayol and Cornet, 1997] computes the three-dimensional displacements caused by sources such as tensile cracks, faults or reservoirs of arbitrary geometry located beneath realistic topography. The eastern flank of Piton de la Fournaise volcano has topographical slopes steeper than 20 degrees, and Fukushima et al. [2005] found that neglecting the topography resulted in poor modeling at depth and in overestimations of overpressure or opening, height (both about 30\%), and volume (about 20\%) of the modeled intrusion for their case study.

The medium is assumed to be linearly elastic, homogeneous and isotropic. From seismic velocities [Brenguier et al., 2007; Nercessian et al., 1996; Prôno et al., 2009] and in situ densities [Rançon et al., 1989], dynamic Young's moduli of $7.5 \mathrm{GPa}$ and $25 \mathrm{GPa}$ are calculated for depth ranges

Table 2. Dike model parameter names and definitions

\begin{tabular}{ll}
$P_{0}$ & Overpressure (MPa) \\
$\delta$ & Dip angle $\left(^{\circ}\right)$ \\
$\phi$ & Angle between the line connecting the top and bottom \\
& middle points and the dipping direction $\left(^{\circ}\right)$ \\
$h$ & Elevation of the bottom middle point $(\mathrm{m})$ \\
$\tilde{L}$ & Length of the bottom side scaled to that of the top side \\
$\psi$ & Horizontal angle between the top and bottom sides $\left(^{\circ}\right)$ \\
$\theta$ & Vertical angle of the bottom side $\left(^{\circ}\right)$ \\
$d$ & Along-dip height of the en echelon segments $(\mathrm{m})$ \\
\hline
\end{tabular}
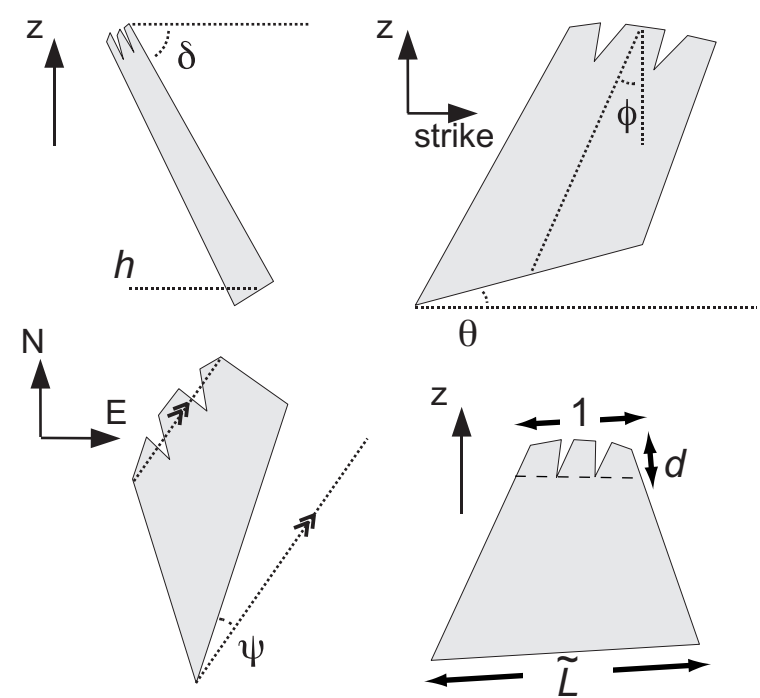

$\theta$

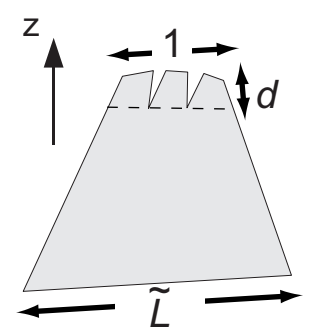

Figure 2. Seven parameters that determine the dike model geometry. See Table 2 for the definitions of the parameters. of $700-1300 \mathrm{~m}$ and $1300-1900 \mathrm{~m}$ respectively. Basaltic rocks are generally porous; Ryan [1987b] measured the porosity of basaltic rocks collected on the Big Island of Hawaii and found a range of $14.3-21.4 \%$. The ratio of dynamic to static Young's moduli is generally a function of porosity, and experiments performed by Cheng and Johnston [1981] predict the ratio to be from 0.1 to 0.4 for a depth range of 0 $2 \mathrm{~km}$. Thus, an increase of the static Young's modulus from $0.75 \mathrm{GPa}$ (surface) to $10 \mathrm{GPa}(2 \mathrm{~km})$ would be expected. In this study, we assume the Young's modulus to be $5 \mathrm{GPa}$, which is the mean value. While the homogeneous assumption (a constant Young's modulus for all depths) imposes a bias on our results, this assumption makes BEM computations fast enough so that Monte-Carlo inversions, each of which requires thousands of forward computations, are manageable. The consequence of the homogenous assump-

(a)

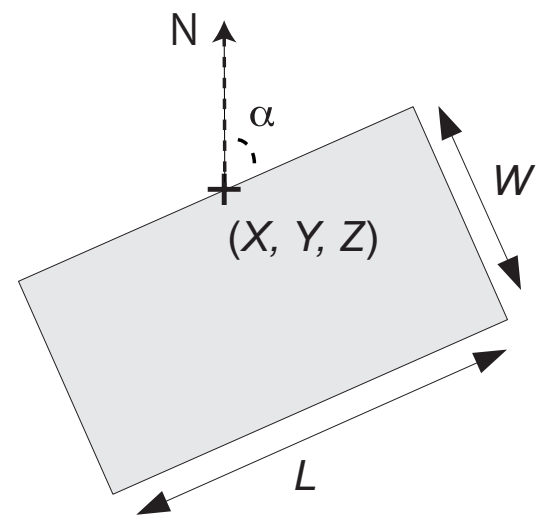

(b)
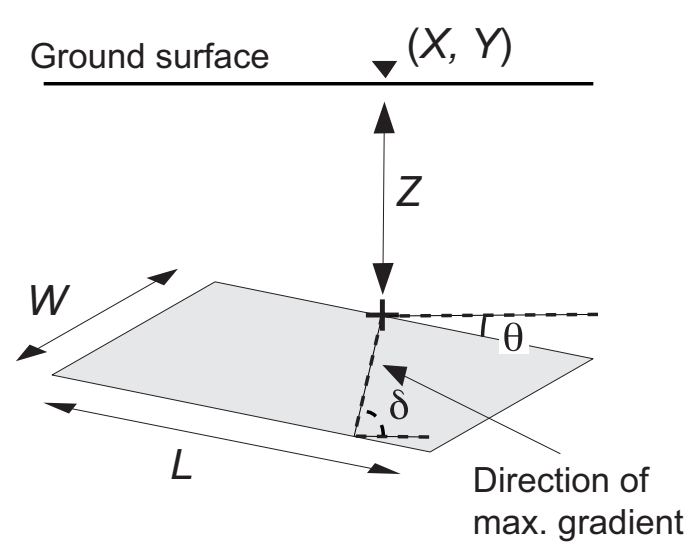

Figure 3. Parameters defining the geometry and location of a rectangular pressure source. See Table 3 for the definitions of the parameters. (a) Plane view. (b) Lateral view. 
tion will be discussed later, in section 4.8. We also assume a Poisson's ratio of 0.25 .

A dike is assumed to be a quadrangle projected onto a curved plane. It is curved because eruptive fissures are, in general, not aligned in a straight line. The top is fixed for the moment to a smooth trajectory of en echelon eruptive fissures. The bottom can be a straight or curved line, and its position and geometry are determined by six parameters (Table 2, Figure 2). Three parameters, i.e., the dip angle $\delta$, the angle between the line that connects the top and bottom middle points and the dipping direction $\phi$, and the elevation of the bottom middle point $h$, determine the position of the bottom middle point. The other three parameters, i.e., the length of the bottom side scaled by that of the top side $\tilde{L}$, the horizontal angle between the top and bottom sides $\psi$, and the vertical angle of the bottom side $\theta$, determine the position of the two end points of the bottom side. This parameterization allows inversion searches to be restricted to mechanically plausible dike geometries.

Eruptive fissures associated with the five studied eruptions have en echelon arrangements. Following Delaney and Pollard [1981], we assume that the en echelon pattern is caused by a rotation of the minimum principal stress close to the ground surface. We model the en echelon segments by dividing the basic quadrangle shape into a shallow and a deeper part, at a downdip distance $d$ from the ground surface. The top of the en echelon segments is fixed at the location of the eruptive fissures observed and mapped by Villeneuve [2000].

Dikes are further assumed to open in response to magma overpressure (the difference between the magma pressure and the normal stress exerted on the dike surface), which is assumed to be uniform over the whole dike surface. It is also assumed that there is no shear stress change on the dike surface. The BEM determines an opening distribution which meets these stress boundary conditions. While it may seem more reasonable to assume a depth-dependent or more complex overpressure model, we do not attempt to make such assumptions because; 1) an inversion (not presented in this paper) permitting a depth-gradient overpressure for the March 1998 northern dike resulted in a wide range of acceptable gradients from -0.013 to $0.010 \mathrm{MPa} / \mathrm{m}$, indicating that the gradient can not be well constrained, and 2) we do not have a good a priori knowledge of the stress field, hence of the overpressure, of the shallowest part of the edifice.

Adding a constant overpressure to the seven geometrical parameters, we have a total of eight model parameters. This is comparable to the frequently-used rectangular dislocation model of Okada [1985], which has eight parameters (this reduces to six if we fix the location of the intrusion as we do in our study). Yet, boundary element approaches have an advantage such that one can obtain opening distributions of dikes that are physically much more realistic [Cervelli et al., 2002; Fukushima et al., 2005; Zeller and Pollard, 1992].

For the analysis of the March 1998 eruption, we also use a rectangular intrusion model (Figure 3), which is described by nine parameters (Table 3 ). Three define the location

Table 3. Rectangular model parameter names and definitions

\begin{tabular}{ll}
\hline$P_{0}$ & Overpressure (MPa) \\
$X$ & East coordinate of the top middle point $(\mathrm{km})$ \\
$Y$ & North coordinate of the top middle point $(\mathrm{km})$ \\
$Z$ & Elevation of the top middle point $(\mathrm{m})$ \\
$\delta$ & Dip angle $\left(^{\circ}\right)$ \\
$\alpha$ & Strike angle $\left(^{\circ}\right)$ \\
$\theta$ & Vertical angle of the bottom side $\left(^{\circ}\right)$ \\
$L$ & Length $(\mathrm{m})$ \\
$W$ & Width $(\mathrm{m})$ \\
\hline
\end{tabular}

$(X, Y, Z)$, and five define the geometry (dip angle $\delta$, strike angle $\alpha$, vertical angle of the top and bottom sides $\theta$, length $L$, and width $W$ ). The last parameter is a constant overpressure $P_{0}$.

The topography mesh is constructed from the DEM used for the interferogram computations. The mesh is made fine close to the deformation sources and is coarsened in low deformation areas. To limit errors caused by the finite extension of the ground surface mesh, its extension is chosen to be five times the presumed deformation source dimensions. For inversions, dike meshing is automated.

We use the neighbourhood algorithm inversion method [Sambridge, 1999a, b], which consists of two stages: search and appraisal. In the search stage, good data-fitting regions of the model space are systematically explored, which allows for the identification of multiple minima. The data fit is evaluated through a misfit function written

$$
\chi^{2}(\mathbf{m})=\left(\mathbf{u}_{o}-\mathbf{u}_{m}\right)^{T} \mathbf{C}_{\mathbf{d}}{ }^{-1}\left(\mathbf{u}_{o}-\mathbf{u}_{m}\right)
$$

where $\mathbf{u}_{o}$ and $\mathbf{u}_{m}$ are vectors of observed and modeled LOS displacements, respectively, and $\mathbf{C}_{\mathbf{d}}$ is a data covariance matrix. When available, interferograms obtained for different LOS directions are simultaneously used in an inversion (see Table 1) by using the observed and modeled data vectors formed by concatenating the vectors for different interferograms.

The observed displacement vector $\mathbf{u}_{o}$ is created by subsampling the unwrapped InSAR displacements. Subsampling is required in order to make the computations numerically manageable. A previous study [Fukushima et al., 2005] compared several subsampling methods (a regular grid, a circular grid such that the point density is greatest close to the eruptive fissures, a quadtree type grid [e.g. Jónsson et al., 2002] and a grid where nodes correspond to ground mesh modeling nodes) and concluded that an initial model can be equally well retrieved using these different methods when a full data covariance matrix was taken into account.

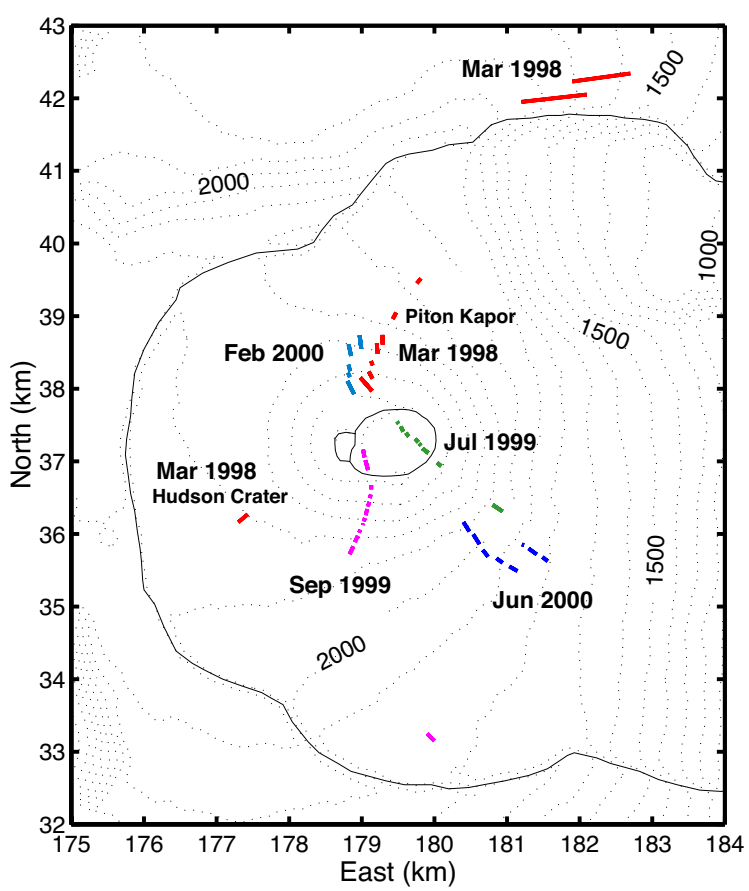

Figure 4. Locations of the eruptive fissures for the five studied eruptions [Villeneuve, 2000]. Contour lines are drawn every 100 meters. Summit craters and Enclos Fouqué borders are outlined. 
Fukushima et al. [2005] found that the random fluctuation of atmospheric phase delay on Piton de la Fournaise can be appropriately modeled by an exponential autocorrelation function. The covariance of the $i$-th and $j$-th data points is therefore assumed to be

$$
\mathbf{C}_{\mathbf{d}}(i, j)=\mathbf{C}_{\mathbf{d}}(j, i)=\epsilon^{2} \exp \left(-\frac{r_{i j}}{a}\right) .
$$

Here, $\epsilon^{2}$ and $a$ are the variance and correlation distance, respectively, and $r_{i j}$ is the distance between the $i$-th and $j$-th data points. The variance $\epsilon^{2}$ and correlation distance $a$ are set to plausible values based on the properties of the residual data of preliminary inversion runs. If the residual data of an inversion have significantly different values of $\epsilon^{2}$ and $a$, then the parameters are adjusted and an inversion is rerun. The mean values of the variance and the correlation distance used by all the inversions presented in this paper are $5.5 \times 10^{-4} \mathrm{~m}^{2}$ and $826 \mathrm{~m}$, respectively.

In the appraisal stage, the posterior probability density function of the model parameters is computed by a Monte Carlo integration technique, using model misfit values calculated in the search stage [Sambridge, 1999b]. Confidence intervals of model parameters can be obtained from one-dimensional marginal posterior probability density functions. More detailed description of the whole method is given in Fukushima et al. [2005]. The applicability of the method has been confirmed by synthetic tests [Fukushima et al., 2005].

\section{Applications to the 1998-2000 Eruptions}

The five 1998-2000 eruptions occurred in an alternating spatial pattern (Figure 4), with eruptive fissures opening successively on the northern flank (March 1998), at the summit (July 1999), on the southern flank (Sept. 1999), returning to the northern flank (Feb. 2000), and then on the southeastern flank (June 2000). This section determines the models associated with these five eruptions using the method described in the previous section but with slight modifications to allow for adaptation to each problem.

\subsection{Additional measures of model misfits}

Because the misfit function used in the inversions only gives an indication of the data fit of models relative to each other, we discuss the model fit using a more intuitive indicator, which is the percentage of explained data, defined as

$$
S(\%)=\left\{1-\frac{\sum_{i}\left(u_{o}^{i}+l-u_{m}^{i}\right)^{2}}{\sum_{i}\left(u_{o}^{i}+l\right)^{2}}\right\} \times 100,
$$

where $u_{o}^{i}$ and $u_{m}^{i}$ are $i$-th elements of $\mathbf{u}_{o}$ and $\mathbf{u}_{m}$, respectively, $l$ is a constant offset of interferometric data determined in such a way that $S$ is minimized.

We also use the Akaike's Information Criterion (AIC) $[$ Akaike, 1974] to compare different models explaining the same data set with different numbers of model parameters. From a statistical point of view, the model having the minimum AIC is the best model. The AIC for model $\mathbf{m}$ is defined by

$$
\mathbf{A I C}(\mathbf{m})=-2 \log L(\mathbf{m})+2 n,
$$

where $L(\mathbf{m})$ and $n$ are the likelihood for the model $\mathbf{m}$ and the number of model parameters, respectively. The likelihood can be written as

$$
L(\mathbf{m})=(2 \pi)^{-N / 2}\left|\mathbf{C}_{\mathbf{d}}\right|^{-\mathbf{1} / \mathbf{2}} \exp \left(-\frac{\chi^{2}(\mathbf{m})}{2}\right)
$$

where $N$ is the number of data points and $|\cdot|$ denotes the determinant. Equations (4) and (5) leads to

$$
\mathbf{A I C}(\mathbf{m})=N \log (2 \pi)+\log \left|\mathbf{C}_{\mathbf{d}}\right|+\chi^{2}(\mathbf{m})+2 n .
$$

\subsection{Consideration of mechanical interactions}

When dikes intrude close to each other in space and time, they interact mechanically. A rule of thumb for mechanical interactions to be effective is that the distance between the sources is less than three times the greatest source dimension [Jaeger et al., 2007]. The combined effect of the sources is treated in three different ways depending on the distance and time lag between the dike emplacements.

Case (a): Dikes intrude far from each other. In this case, the sources are assumed not to have mechanically interacted. An appropriate strategy is to then proceed using successive inversions, starting by first inverting displacements around one source, and next inverting the residuals for the other source (Figure 5a).

Case (b): Dikes are emplaced close to each other, but with a time lag long enough to allow the cooling and solidification of one source before the next one is emplaced. In this case, the second intrusion is influenced by the stress change due to the initial intrusion. Since we do not have a priori knowledge about the stress field, we assume here that the normal stress on the second dike surface is unperturbed by the first one and neglect any stress interaction. We can not follow the strategy of Case (a), however, because the displacements due to the two intrusions overlap. An appropriate inversion strategy for such a case is to generate forward models by computing the contribution of each source independently and to sum the corresponding modeled displacements. Inversions are performed considering all source parameters simultaneously (Figure 5b).

Case (c): Dikes are close to each other and were emplaced shortly after one another. In this case, mechanical interactions probably took place. Inversions should be performed by simultaneously taking into account all sources in a single boundary element computation (Figure 5c).

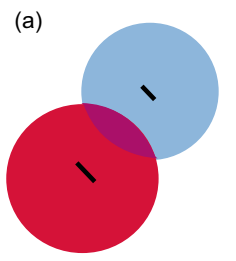

(b)
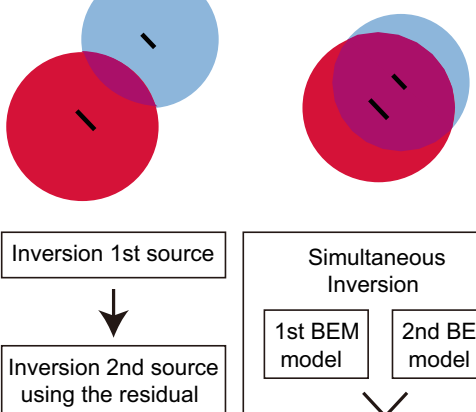
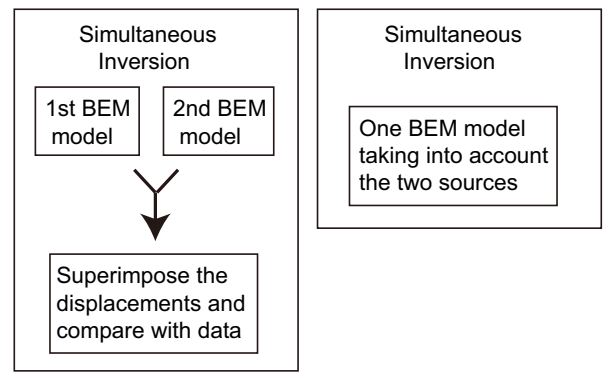

Figure 5. When several pressure sources are emplaced, different modeling strategies must be followed depending on the time lag between the emplacement of the different sources and their distances. (a) Pressure sources far from each other, (b) Sources are close to each other, but with sufficient time delay to allow the cooling of one source before the next is emplaced. (c) Sources close to each other and simultaneously emplaced. 
The first case, where pressure sources are far from each other, allows the successive determination of a relatively large number of source model parameters, while the latter two cases require either the number of parameters to be reduced or to tune the Monte-Carlo inversion search to be intense in a small area of the model space rather than a larger area. Intense exploration of a small area increases the risk for the solution to be caught in a local minimum.

\subsection{The March 1998 Eruption}

The March 1998 eruption occurred after five and a half years of quiescence and was the first of the new cycle of eruptions. Pre-eruptive micro-earthquakes, which started 36 hours before the onset of the eruption, clearly migrated from $5 \mathrm{~km}$ below sea level upward toward the summit [Battaglia et al., 2005]. Summit deformation began about an hour before the eruption onset, when the hypocenters of the microearthquakes reached sea level. Lava was emitted from three sets of fissures (Figure 4). One of the northern flank fissures (the Piton Kapor vent) remained active for 6 months, until 21 September, and produced $6.0 \times 10^{7} \mathrm{~m}^{3}$ of lava making this eruption the second largest eruption of Piton de la Fournaise by volume in the 20th century. The two other sets of fissures opened on the southwestern flank (Hudson crater) and to the north, beyond the Enclos Fouqué. Geochemical analysis indicates that lava emitted on the south flank was rapidly transfered from mantle depths, whereas lava emitted on the northern flank had assimilated shallow level material [Vlastélic et al., 2005].

Displacements associated with this eruption were measured by one interferogram from the east (Table 1). At the time of the second image acquisition (30 July 1998), the eruption was still ongoing at Piton Kapor. However, an interferogram of the July 1999 event (Figure 8b), whose first image was taken on 1 April 1998, shows no global signal corresponding to the eruptive vent of the 1998 eruption, indicating that most of the ground deformation associated with the 1998 eruption had occurred before 1 April 1998. No interferometric signal indicates deformation related to the eruptive fissures outside the Enclos Fouqué.

After testing different numbers of dikes with different geometries, we have selected a model in which the displacements are caused by the sum of (1) an inflation of a deep sill-like body that accounts for the broad fringes located on the southern flank away from the eruptive fissures, (2) a dike beneath the northern eruptive fissures, and (3) a dike beneath the southwestern eruptive fissures. We assume that the sources are far enough from each other not to have interacted, and we follow the first inversion strategy (Figure 5a). Firstly, the sill source is modeled as a rectangle using the eight geometrical parameters given in Figure 3. The inversion search, using subsampled data in the broad-fringes region (white dots in Figure $6 \mathrm{~b}$ ), shows a sill dipping $30^{\circ}$ to the southeast, located approximately $2000 \mathrm{~m}$ beneath the summit (Table 4, Figure 6a). Next, the residual data are subsampled around the northern dike, and are inverted for the northern dike (white dots in Figure $7 \mathrm{~b}$ ). The same procedure is then applied to the southern dike (green dots in Figure 7b). The best-fit dikes are approximately $1 \mathrm{~km}$ high and dip eastward (seaward) at $36^{\circ}$ and $53^{\circ}$ for the northern and southwestern dikes, respectively (Table 4 and Figure 7a). Two to three residual fringes are present (Figure 7b), which suggests our model is oversimplified. The connection details between the sill and dikes are beyond the resolution of interferometric data.

This model is mechanically plausible. The broad interferometric fringes are created by a sill-like inflating source at depth located above the magma source inferred from the analysis of inter-eruptive displacements [Peltier et al.,
2007, 2008]. The northern and southern dike heights are consistent with those determined for other eruptions, as explained later. While we manage to obtain the same degree of data fit, and in fact a smaller AIC value (Table 5), with a two-dike model consisting of the northern and southwestern dikes only, the depth of the bottom of these dikes (-121 to $560 \mathrm{~m}$ and 51 to $926 \mathrm{~m}$ above sea level for the northern and southern dikes, respectively, at $90 \%$ confidence) is significantly greater than the dikes determined for the other eruptions. We attach importance to consistency with other eruptions, rather than the number of model parameters needed to explain the data, and we prefer the three-source model as the model for this eruption.

Sigmundsson et al. [1999] and Battaglia and Bachèlery [2003] applied a rectangular dislocation model of Okada [1985] to similar RADARSAT-1 interferometric data and continuous tilt data, respectively, and determined a dike model whose characteristics (dip, height and opening) were broadly consistent with our northern dike model. The silllike inflation we determine is consistent with inversions of gravity data [Bonvalot et al., 2008], which showed the observations could not be solely explained by the northern dike intrusion, but that an additional mass increase at sea level was required. None of these other models called for a dike at the location of the southwestern flank (Hudson Crater). Indeed, we determine that this dike corresponds to the small volume of magma of $0.3 \mathrm{Mm}^{3}$, representing only $4 \%$ of the volume intruded in the northern dike $\left(3.2 \mathrm{Mm}^{3}\right)$ and the sea-level sill $\left(4.9 \mathrm{Mm}^{3}\right)$. This explains why the data can be satisfactorily explained without this dike.

\subsection{The July 1999 Eruption}

On 19 July 1999, 50 minutes before the eruption onset, a seismic swarm at sea level as well as tilt and extensometric data anomalies, were detected by the OVPF monitoring network. En echelon eruptive fissures located within and east of the Dolomieu crater (Figure 4) emitted lava for three days. Then the activity paused for three days before new fissures formed $1 \mathrm{~km}$ farther to the southeast and emitted lava until 31 July.

Displacements associated with this eruption were measured by one interferogram captured from the east of the volcano (Figure 8b). As the eruption proceeded in two steps, it is assumed that two dikes were emplaced during this eruption. Because dikes with thicknesses of one meter should solidify in three days [e.g. Parfitt and Wilson, 2008], we assume that the first dike had solidified by the time the second one was emplaced. Taking into account the fact that the dikes are close to each other, we adopt the second inversion strategy (Case (b), Figure 5b), i.e., a simultaneous inversion of two dikes with separate BEM computations for each dike. To make the inversion numerically feasible, we fix some parameters. Based on preliminary inversion results, the height of the segments connecting the summit dike to the surface (parameter $d$ ) is fixed to $200 \mathrm{~m}$, resulting in seven parameters for this dike. The second dike geometry on the southeastern flank is assumed to be close to a rectangle with its top and bottom sides parallel to the topography, leaving four model parameters (dip angle $\delta$, bottom elevation $h$, depth of the dike top $d$ and overpressure $P_{0}$ ) for this dike.

An inversion for all 11 parameters leads to a model that explains $96 \%$ of the data (Figure $8 \mathrm{~b}$ ). This model consists of a triangular dike, in which the width of the dike narrows with depth below the Dolomieu eruptive fissures and a $350 \mathrm{~m}$ high dike starting $254 \mathrm{~m}$ below the ground (Table 4 and Figure 8a).

\subsection{The September 1999 Eruption}

The 28 September 1999 eruption was characterized by an 80 minute long pre-eruptive seismic crisis and 50 minute long pre-eruptive deformation. Eruptive fissures opened from 
the summit to the southern flank (Figure 4). The eruption ended 25 days later on 23 October, 1999.

Similar to the previous eruptions, displacements were only measured by one interferogram taken from the east of the volcano (Figure 9b). Based on preliminary inversions, the upper part of the quadrangle dike model is assumed to be entirely connected to the volcanic surface, and the bottom side of the dike is assumed to have the same curvature as the upper side, rather than being a straight line. The best-fit model explains $93 \%$ of the observed data. The dike has a mean hight of $250 \mathrm{~m}$ and is subvertical (Table 4).

As there are some residuals on the eastern side of the dike, and as the model-determined dike is about $1000 \mathrm{~m}$ above the pre-eruptive seismic swarm, the presence of a subvertical feeder dike is also investigated. It is found that a vertical dike (Figure 9a), whose bottom lies approximately $1000 \mathrm{~m}$ beneath the summit, slightly improves the data fit with $94 \%$ of the data explained (Figure 9b).

\subsection{The February 2000 Eruption}

The inversion results for the February 2000 eruption have already been published [Fukushima et al., 2005]. The location of the eruptive fissures is indicated on Figure 4. The inversion result is listed in Table 4 . This eruption was associated with a single intrusion causing relatively less complex displacements, which allowed a straightforward application of the procedure described in section 3 . The dike is inferred to be roughly trapezoidal, dipping seaward $\left(61.0^{\circ}-67.3^{\circ}\right)$ with its bottom passing $800-1000 \mathrm{~m}$ beneath the summit. The model parameters were well constrained by using two interferograms from the west (ascending orbit) and two interferograms from the east (descending orbit).

\subsection{The June 2000 Eruption}

Unlike previous eruptions, increases in the seismicity rate and the deformation signal amplitudes started about two weeks before the eruption onset. On 23 June 2000, a seismic crisis occurred simultaneously with tilt changes. Both the seismicity and tilt changes indicated migration of an intrusion toward the summit and the southeastern flank of the volcano, where two sets of eruptive fissures opened on 23 June. The activity quickly localized to the lower eruptive fissures and lasted until 30 July.

Three interferograms, two from the west and one from the east, captured the displacements associated with this eruption (Figure 10b). The original interferogram taken from the east shows altitude-correlated fringes, which are removed assuming an altitude-dependent phase model [Fukushima, 2005]. To simplify the modeling, each of the two sets of eruptive fissures is approximated by continuous fissures. The three interferograms are first simultaneously inverted assuming a single dike model with the standard seven geometrical parameters and an overpressure. The best-fit dike model explains $74 \%$ of the data and its bottom is located $1300 \mathrm{~m}$ below the volcanic surface, parallel to the topography.

In order to improve the data fit, an along-dip curvature is additionally introduced in an inversion, resulting in nine parameters. The dike surface is assumed to be a parabola in the along-dip direction, and the curvature is defined by the angle between the line connecting top and bottom points and the tangential line of the parabola at the top and bottom points. This model explains $81 \%$ of the data, leaving four to five residual interferometric fringes for each direction (Figure 10b). The geometry of the best-fit model is significantly curved in the along-dip direction (Figure 10a). Similar to the flat dike model, the bottom of the dike is located $1000-1300 \mathrm{~m}$ below the volcanic surface and is parallel to the topography. While curved dikes are not often found in the field, some have been identified in the exposure of the Cilaos dike complex at Piton des Neiges [Maillot, 1999], which is an older volcano located on the same island.
We have also tested a model with an additional curvature of the dike bottom in the direction normal to the dike surface as well as a two-dike model. The former model results in practically the same inferred dike geometry as the "straight-bottom model" as is shown in Figure 10. The latter model calls for our third inversion strategy (Figure 5c), i.e., a simultaneous inversion with dike interactions taken fully into account, resulting in a 14 parameter inversion (the full parametrization described in section 3 except for the height of the segmented part $d$ which was fixed to zero for each dike). In order to achieve a solution convergence within an acceptable time, the number of models evaluated at each iteration $n$ in the neighbourhood algorithm is set to five. The percentage of explained data $(78 \%)$ is less than our single dike model. It should be noted that this two-dike inversion might have been caught in a local minimum because of a small $n$, which still leaves open the possibility of having two dikes for this eruption.

The AIC value of the model with the along-dip curvature (Figure 10) is smaller than those of the standard quadrangular shape and the two-dike model (Table 6), which leads us to select the single curved dike model as our preferred model. The relatively large residuals in Figure 10b suggest that the intrusion was more complex than we assumed.

\subsection{Findings from the InSAR data inversions}

Our inversion results commonly suggest laterally elongated shallow dikes (Figure 11). All the preferred dike models are located shallower than $1300 \mathrm{~m}$. The depth is generally well constrained, with uncertainties (subscripts and superscripts for $h$ in Table 4 ) within \pm 300 m for most of the cases.

Even though we permitted an inclined bottom (determined by $\theta$; see Figure 2), our results indicate that the dike bottom is always parallel to the topographical slope. This seems reasonable because the stresses in the edifice are, in the first order, a function of depth. Indeed, for a homogenous axisymmetrical edifice, gravitational stresses are strongly correlated to depth [Cayol and Cornet, 1998], rock density increases with depth as a result of increased contractancy with confining pressure [Ryan, 1987a, b], and volcanic deposits are emplaced parallel to the edifice slope.

The observed interferograms for the March 1998 and June 2000 eruptions could not be fully explained. Among our assumptions, the homogeneity assumption is probably causing most of the unexplained fringes. Basaltic volcano edifices generally contain sizable pores and fractures that gradually close as the depth increases because of increasing pressure [contractancy effect, Ryan, 1987a, b]. The contractancy causes two similar effects; the effective Young's modulus at shallow depths, where porosity is large, is smaller than that at greater depths, and the confining pressure (hence the normal stress on the dike surface) increases nonlinearly with depth in response to a gradual increase in density with depth. Intrusions are more dilatant at shallower depths because of these two effects, i.e., the variation in the Young's modulus [e.g. Bonafede and Rivalta, 1999; Brenner and Gudmundsson, 2004; Morita et al., 1988; Rivalta et al., 2005; Ryan, 1993] and the nonlinear increase in the confining pressure [Morita et al., 1988; Ryan, 1993]. The fact that the residuals are larger for the deepest intrusions of March 1998 and June 2000 supports this speculation.

Best-fit values of overpressure estimated for the studied intrusions range from 0.7 to $6 \mathrm{MPa}$ (Table 4). If we assume that these overpressure values are the consequence of the density difference between magma and rocks, the density contrasts range from 70 to $600 \mathrm{~kg} / \mathrm{m}^{3}$. This range is consistent with the density contrast expected between the fractured porous edifice $\left(1600 \mathrm{~kg} / \mathrm{m}^{3}\right.$ [Gailler et al., 2009] 
to $2300 \mathrm{~kg} / \mathrm{m}^{3}$ [Rousset et al., 1989$]$ ), and basaltic magmas with densities ranging from $2200 \mathrm{~kg} / \mathrm{m}^{3}$ (gas rich) to $2700 \mathrm{~kg} / \mathrm{m}^{3}$ (degassed) [Bonvalot et al., 2008].

\subsection{Contribution to the volcano growth}

Table 7 shows a comparison of the erupted volumes [Staudacher et al., 1998; Staudacher and Cheminée, 1999; Staudacher et al., 1999, 2000] and intruded volumes estimated from the preferred models determined for the March 1998 to June 2000 eruption. The total volume of the preferred dike models is $11.3 \times 10^{6} \mathrm{~m}^{3}$, representing $17 \%$ of the total volume of erupted lava. This indicates that the growth of the volcano edifice was mainly exogenous during the 1998-2000 time period.

It would be expected, then, that the volcanic edifice would become relatively flat because of the dominant lava flows. However, the central cone of Piton de la Fournaise volcano has unusually steep slopes (exceeding $20^{\circ}$ ) on its southeastern and eastern flank. Michon et al. [2009] proposed that the central cone was initially built up as a strombolian cinder cone, and that repetitive dike intrusions later contributed to steepen the southeastern and eastern flank of the cone. Indeed, the slope changes (measured in the direction of maximum gradient) predicted from our dike intrusion models (Figure 12) indicate that steepening of a few hundredth of a degree occurs east of the the $\mathrm{N} 25^{\circ}-30^{\circ} \mathrm{E}$ axis and north of the $\mathrm{N} 120^{\circ} \mathrm{E}$ axis, whereas the western part of the cone is hardly deformed.

The eruptions we analyzed occurred along the northern, southeastern and southern axes (Figures 1 and 4), and this is also the case for the other eruptions in the central cone in the past 30 years [Michon et al., 2009]. Repeated intrusions along the same axes imply that the stress increases due to the intrusions are compensated by a process of stress relaxation. The U-shaped Enclos-Fouqué caldera as well as landslide deposits found on the submarine flank indicate that seaward movement of the eastern flank has taken place in a long timescale [e.g. Bachèlery, 1981; Lénat et al., 1989; Labazuy, 1996]. Recently, co-eruptive SAR interferograms of the April 2007 eruption indicated seaward slips, of the order of a meter, along a subhorizontal decollement [Augier et al., 2008]. It is likely that such episodic slips that occur concurrently with eruptions (and hence with dike intrusions) relax normal stresses on the active axes so that subsequent dike intrusions can take place along them. 
(a)

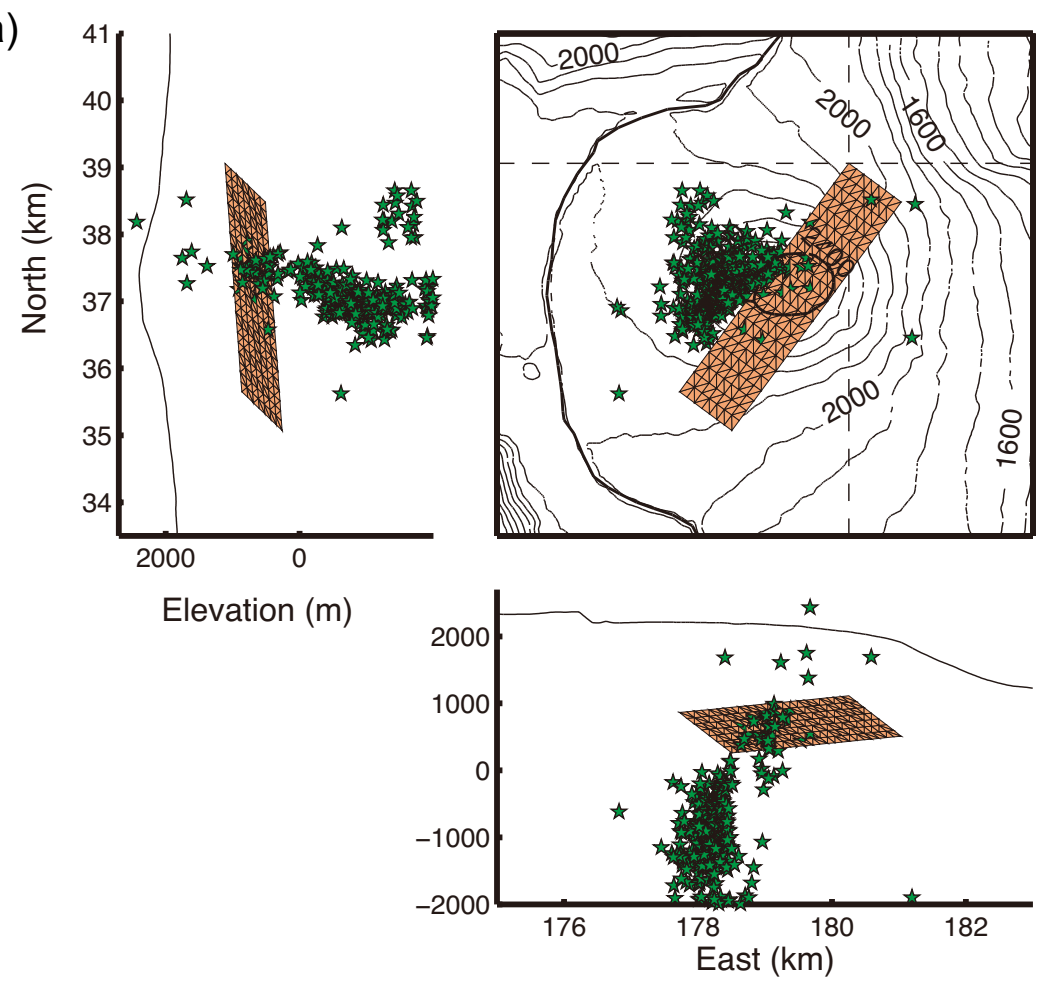

(b)
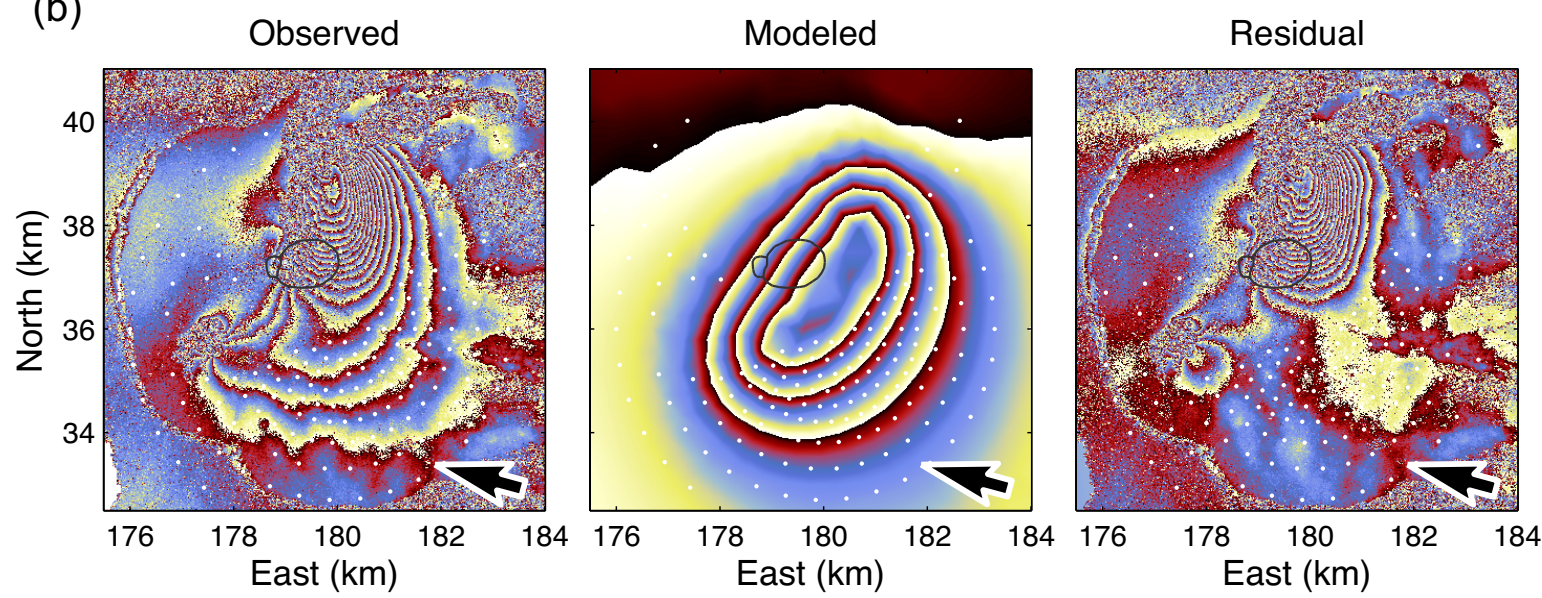

Figure 6. March 1998 eruption. (a) Geometry of the optimum rectangular pressure source obtained from inverting large-wavelength displacements, plotted with the relocated pre-eruption micro-earthquakes that occurred within the 36 hours preceeding the eruption onset (stars) [Battaglia, 2001]. (b) Observed, modeled and residual interferograms, corresponding to the model shown in (a). White dots indicate subsampled data points. One color cycle of white-yellow-blue-red-black corresponds to a displacement of $2.83 \mathrm{~cm}$ toward the satellite. Arrows indicate the surface projection of the LOS direction. 
(a)
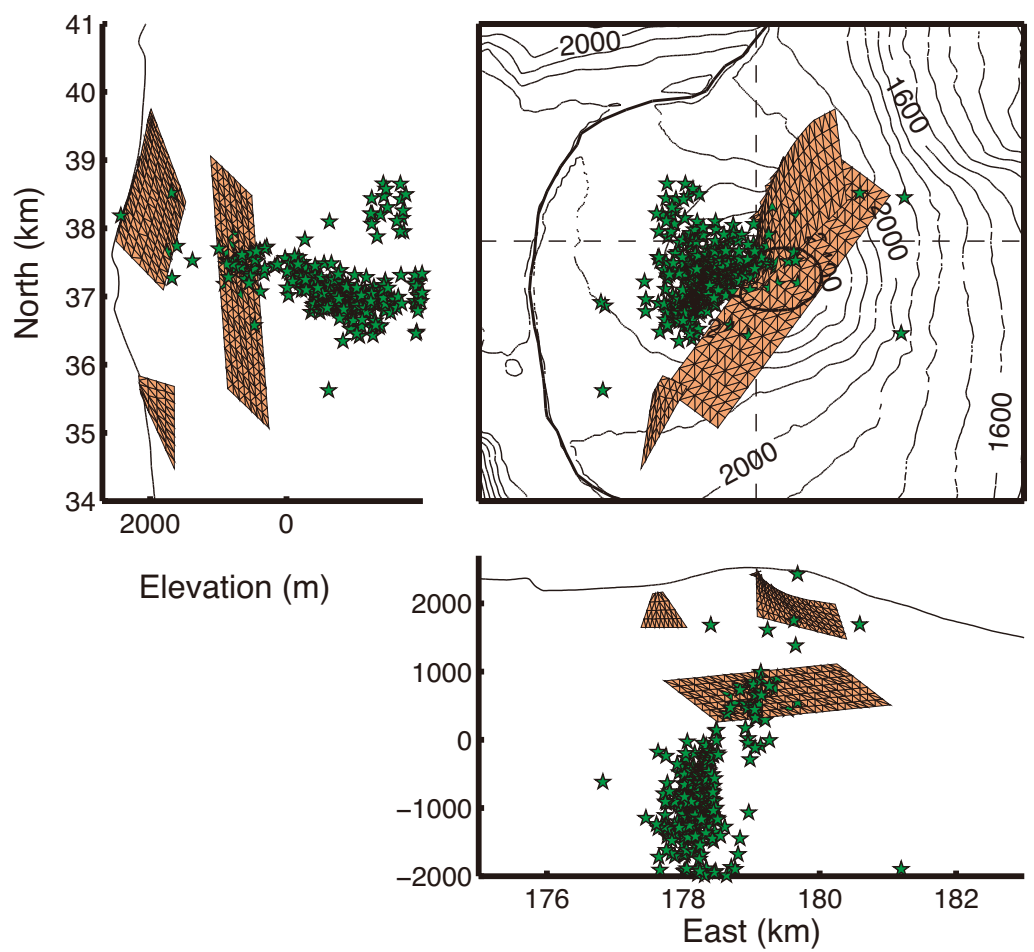

(b)
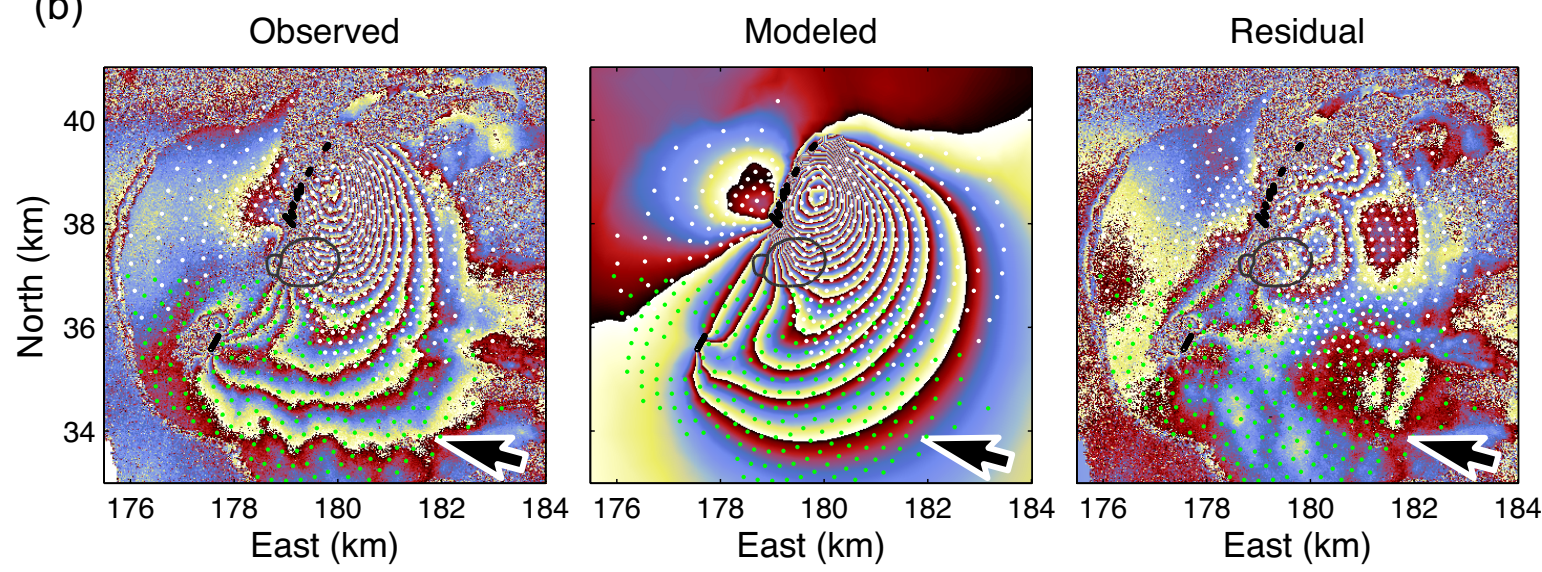

Figure 7. March 1998 eruption. (a) Geometry of the optimum deep sill of Figure 6a and shallow dikes (Table 4) plotted with the relocated pre-eruptive micro-earthquakes that occurred within 36 hours before the eruption onset (stars) [Battaglia, 2001]. (b)The modeled interferogram created from superposing the displacements associated with the three sources shown in (a) is compared with the observed data. White and green dots are the subsampled data points used to invert for the northern and southern dikes, respectively. See Figure $6 \mathrm{~b}$ for the inverted data used to determine the sill. 
(a)
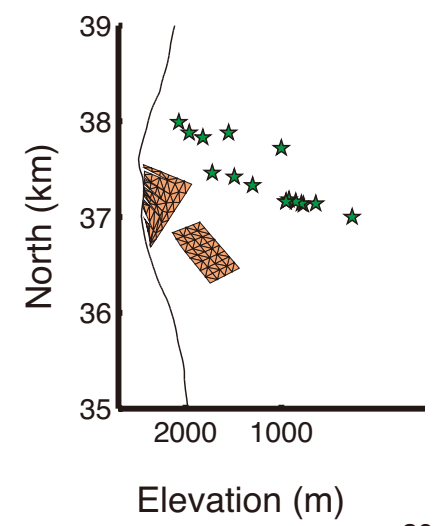
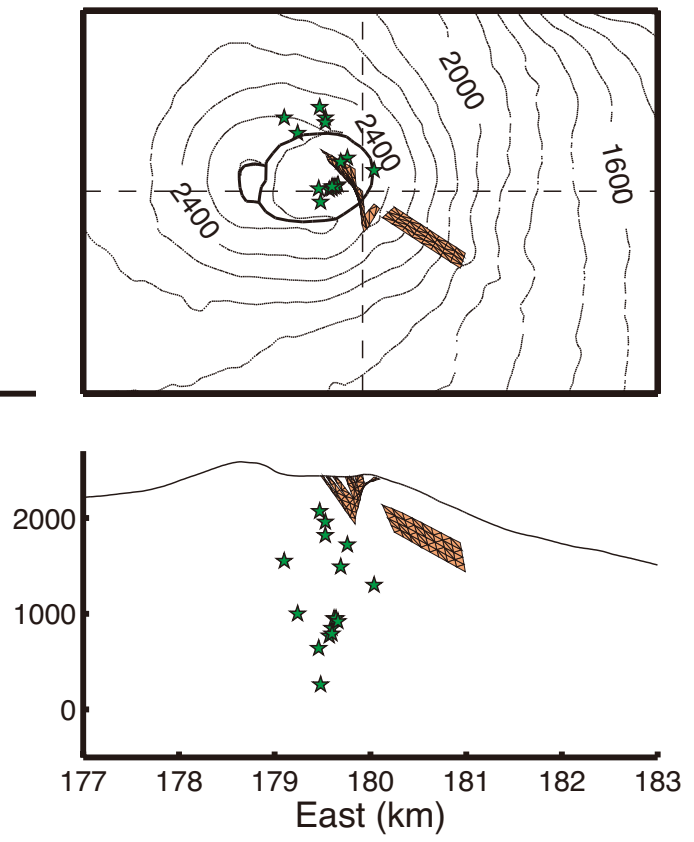

(b)
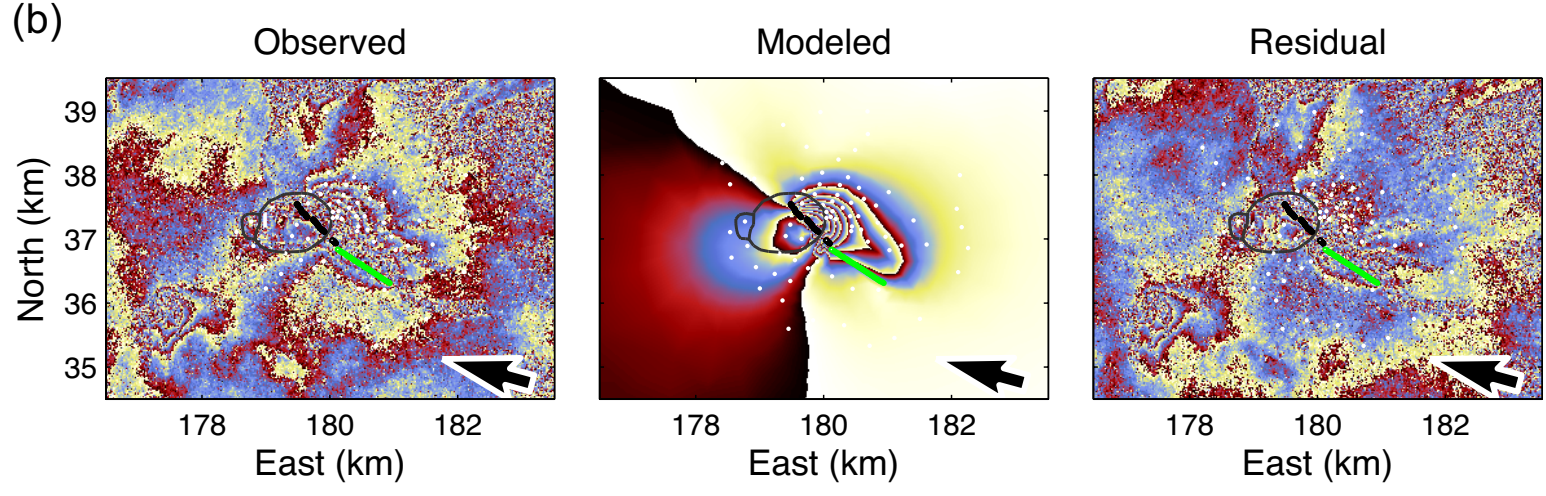

Figure 8. July 1999 eruption. (a) Geometry of the optimum models obtained from a simultaneous inversion of the two dikes associated with the July 1999 eruption (Table 4). Stars are the relocated hypocenters of the pre-eruptive micro-earthquakes that occurred up to 50 minutes before the eruption onset [Battaglia, 2001]. (b) Observed, modeled and residual interferograms for the July 1999 eruption. The black lines indicate the eruptive fissures that are connected to the main dike below the Dolomieu crater, and the green line indicates the top of the second dike. White dots represent subsampled data points used in the inversion. 
(a)

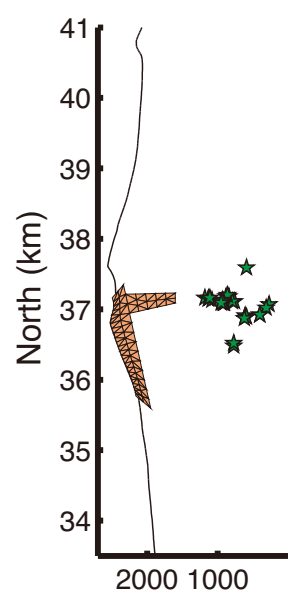

Elevation $(\mathrm{m})$
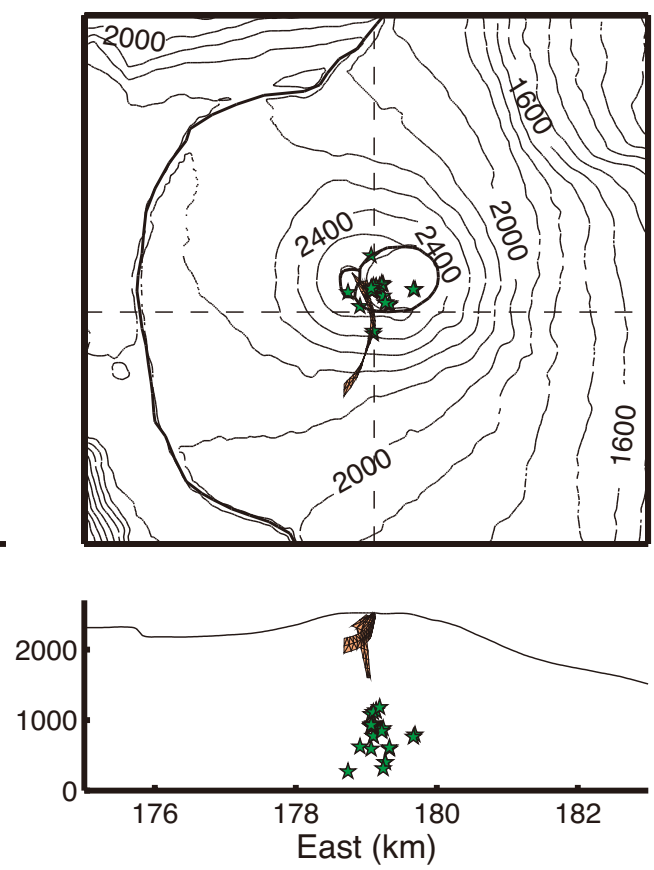

(b)
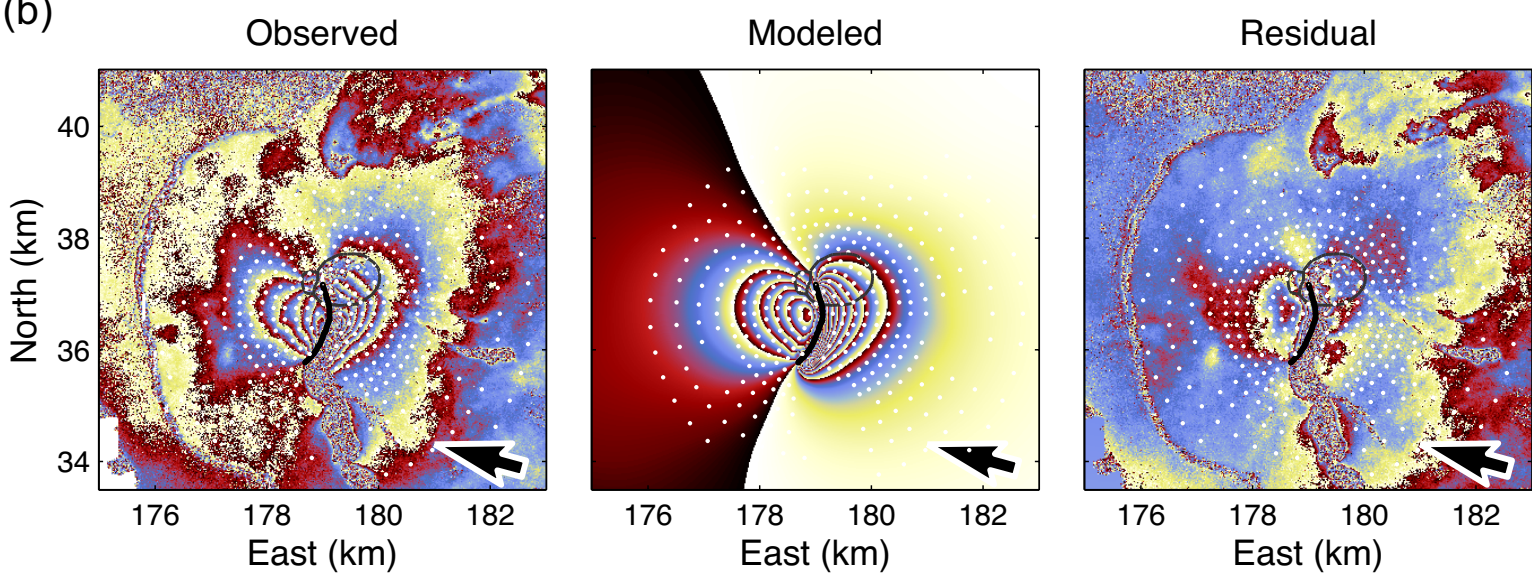

Figure 9. September 1999 eruption. (a) Geometry of the optimum dike model and vertical feeding magma path rooted $1700 \mathrm{~m}$ above the sea level. Relocated pre-eruptive micro-earthquakes that occurred up to 80 minutes before the eruption onset [Battaglia, 2001] are shown as stars. (b) Observed, modeled and residual interferograms for the dike model shown in (a). The heart-shaped displacement pattern is well reproduced. White dots and black line indicate subsampled data points and the presumed eruptive fissure, respectively. 

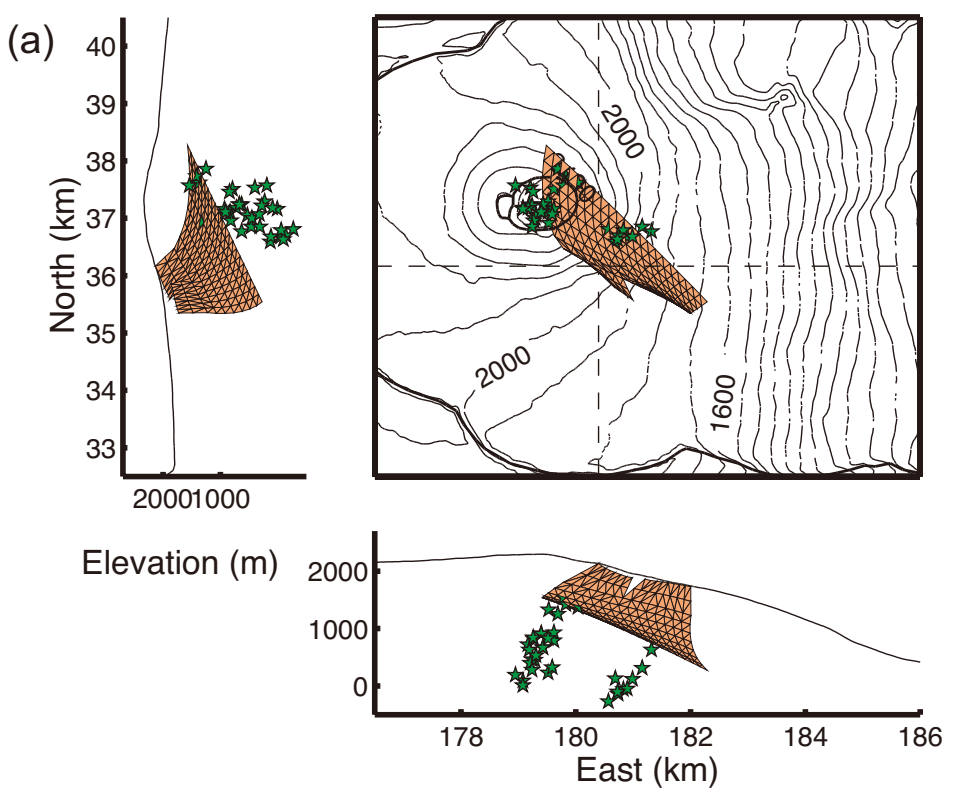

(b)
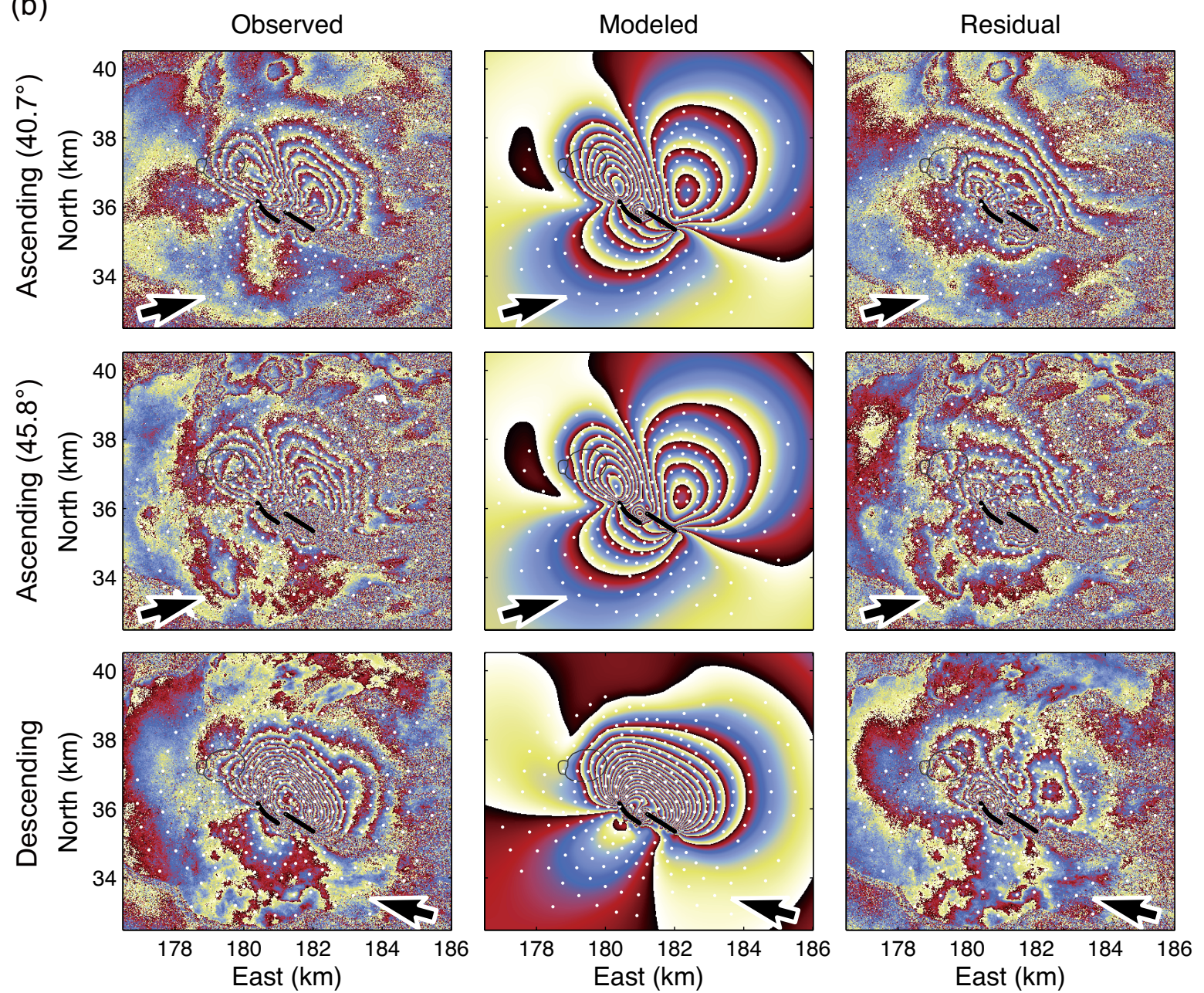

Figure 10. June 2000 eruption. (a) Geometry of the optimum dike (Table 4). The bottom side lies subparallel to the topography at about 1000-1300 m beneath the ground. Stars are the relocated hypocenters of the pre-eruptive micro-earthquakes that occurred up to 14 days before the eruption onset [Battaglia, 2001]. (b) Observed, modeled and residual interferograms for the dike model shown in (a), corresponding to three observed interferograms. Four to five residual fringes for each satellite direction suggest that the intrusion was more complex than we assumed. White dots and black lines indicate subsampled data points and the presumed eruptive fissures, respectively. 


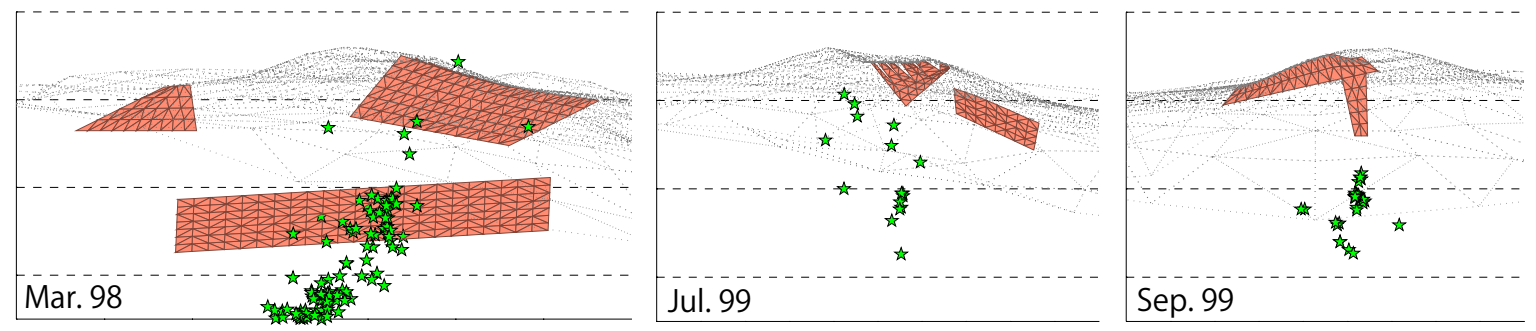

$\star$ : preeruptive seismicity

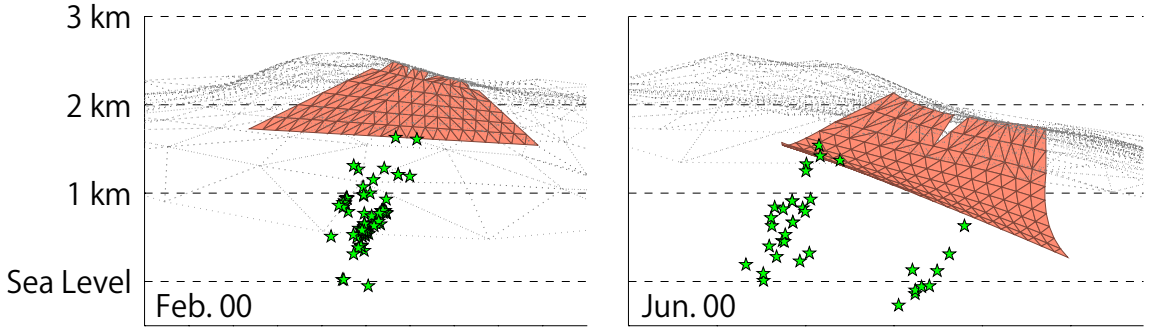

Figure 11. Geometry of magma intrusion models (red) that best explain the observed interferograms, seen horizontally from the direction perpendicular to the strike of the intrusions. Same scale for vertical and horizontal directions. Topographic meshes and pre-eruptive micro-earthquakes are indicated by dotted lines and stars, respectively.

\section{Evolution of Magma Conduits}

In this section, we constrain the temporal evolution of the geometry of magma conduits by combining the results obtained in the previous section with seismic, tilt and visual observations.

\subsection{Lateral injection of magma in shallow dikes}

For the nine eruptions which occurred in 2000-2003, including two of the eruptions we studied, tilt vectors indicate that magma injection was associated with the migration of the center of inflation from the summit toward the future eruptive fissures [Peltier et al., 2005]. For four eruptions in 2003, more detailed modeling of continuous tilt data shows a lateral propagation of dikes at shallow depths [Peltier et al., 2007]. Where possible, visual observations of vent openings can confirm that eruptions start close to the summit and then shift downslope. These strong indications of magma propagating laterally in dikes at shallow depths are consistent with our laterally elongated shallow dikes (Figure 11).

\subsection{Vertical injection of magma in deep dikes}

While shallow laterally-directed magma transfer obviously takes place via dikes, the deeper conduit that transports magma from the source region can either be a dike created for each new eruption, or a cylindrical pipe filled with magma which is used for successive eruptions.

Pre-eruptive seismic swarms are vertically elongated and extend from sea level up to the base of the laterally elongated dikes (Figure 11), with the exception of the March 1998 preeruptive seismic swarm which extended down to $6 \mathrm{~km}$ below sea level. Thus, the deeper magma path is subvertical.

Tilt changes are typically detected simultaneously with, or minutes after, the onset of pre-eruption seismic swarms above sea level [Peltier et al., 2005, 2009]. The March 1998 eruption was an exception; a pre-eruption seismic swarm started 34 hours earlier than tilt changes, at a depth of $6 \mathrm{~km}$ below sea level [Battaglia and Bachèlery, 2003]. But similar to other eruptions, tilt changes before the March 1998 eruption were detected simultaneously with the arrival of the seismic swarm at sea level. These observations indicate that tilt changes at this volcano only become detectable when magma reaches a position near sea level.

For the 1998-2007 period, tilt changes associated with the vertical injection of magma in the edifice were of the order of tens to several hundreds of microradians [Peltier, 2007]. Assuming that the hypocenters of pre-eruptive microearthquakes are indicative of magma conduit extensions, we have compared the maximum tilt amplitudes generated by cylindrical and dike-like conduits in Appendix A. The results show that a cylindrical pipe having a plausible geometry and overpressure can not explain the observed tilt amplitudes of tens of microradians, while a plausible dike can. Thus, at least above sea level, magma is transported in vertically elongated dikes until, or just prior, to the onset of eruptions. This inference applies generally to all the eruptions in the 1998-2007 cycle, because of the systematic precursory tilt signals observed during this period.

\subsection{The level of neutral buoyancy}

The above considerations lead us to propose that magma is injected vertically before being injected laterally. The change in magma injection direction from vertical to lateral is consistent with the time series of tilt, GPS and seismicity data acquired at the volcano for the period 2000-2003 [Peltier et al., 2005, 2007] and for 2004-2005 [Peltier et al., 2008]. Such behavior at Piton de la Fournaise volcano has been proposed before by Peltier et al. [2005] from seismicity and tilt data only, and the present study imposes further constraints especially on the shallow lateral injection. The change in magma injection direction from vertical to lateral during an intrusive event has also been inferred in other tectonic settings based on geophysical [Morita et al., 2006] and geological data [Acocella et al., 2006; Poland et al., 2008], although the time scales may be different.

The shift from vertical to lateral dike propagation requires a level of neutral buoyancy around the depth of the center of the lateral dikes [Ryan, 1987a]. Indeed, a mathematical (analytical and numerical) investigation of Taisne and Jaupart [2009] shows that a dike propagating from depth will grow more in the lateral direction than the vertical direction when it encounters a layer with a lower density than the magma. Such a density structure would be expected from contractancy [Ryan, 1987a, b]. Our preferred dike models are rooted shallower than $1300 \mathrm{~m}$ (Figure 11). Considering also that the uncertainties in the bottom depth are roughly within $\pm 300 \mathrm{~m}$ except for the poorly-constrained southern dike of the March 1998 eruption, we can infer that 

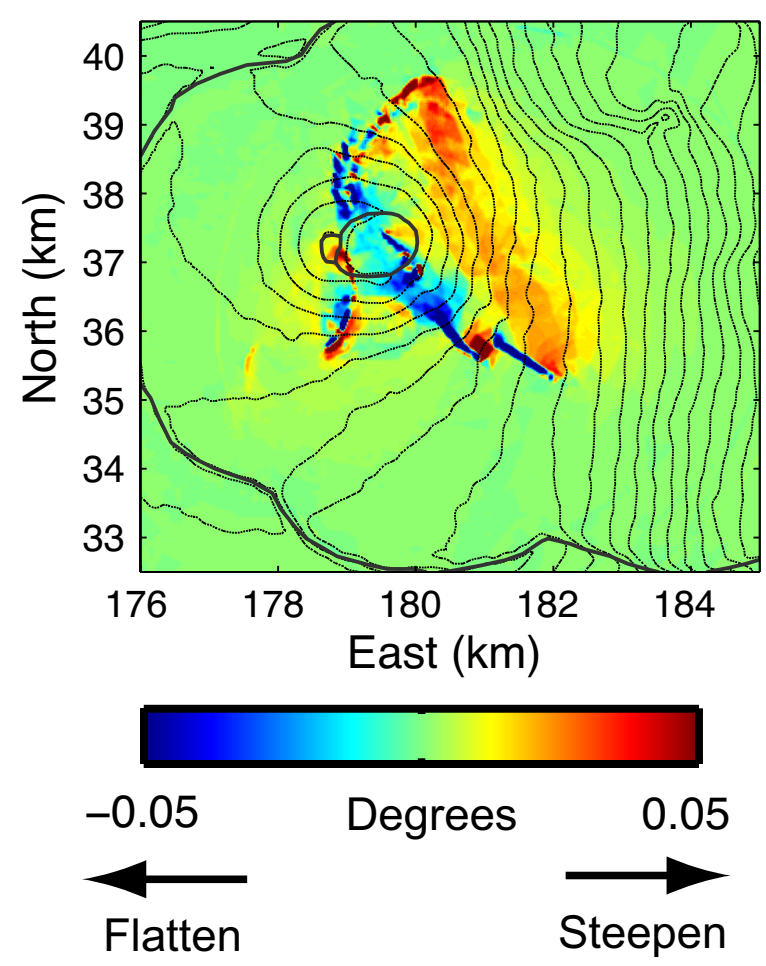

Figure 12. Slope changes (change in the maximum gradient of the topography) predicted from the dike intrusion models for the five eruptions studied (Figure 11). Thick curves are the borders of the Bory and Dolomieu craters and the Enclos-Fouqué caldera. Thin curves are the elevation contours at $100 \mathrm{~m}$ interval.

the levels of neutral buoyancy are, for the studied cases, shallower than $1000 \mathrm{~m}$. For a lithostatic stress state, this implies that the densities of degassed magma and surrounding rock should balance at levels shallower than $1000 \mathrm{~m}$. A recent study of the gravity structure of the volcano [Gailler et al., 2009] indicates that the shallowest part of the central cone is associated with low densities $\left(600-800 \mathrm{~kg} / \mathrm{m}^{3}\right.$ lower than the rocks below) that can be attributed to highly vesiculated rocks that constitute the central cone. The depth of this low density zone is consistent with the shallow levels of neutral buoyancy inferred from the present study. The variable depth of dikes obtained by our analysis indicates a variable level of neutral buoyancy, which may originate from the stress changes due to previous intrusions.

The fact that the deeper, vertical dike-type conduits are not indicated in the interferograms can either be attributed to the deeper conduit being too narrow to cause a signal distinguishable from the signal caused by the shallower conduit [Amelung and Day, 2002; Cayol and Cornet, 1998; Sigmundsson et al., 1999], or to the closure of the deeper conduit after magma transport has ended. Both hypotheses are consistent with positive buoyancy of the deep dike. Indeed, Traversa et al. [2010] estimated, from fluid dynamics models assuming constant influx, that the Piton de la Fournaise 2003 eruption was associated with a vertical propagation of a buoyant dike having a width of $100 \mathrm{~m}$. Deformation associated with such a dike would be hidden by the shallower lateral dike. Analytical models [Weertman, 1971], numerical models $[D a h m, 2000]$ and laboratory experiments $[R i$ valta et al., 2005] show that when buoyant dikes are injected vertically and magma input stops, they close at their lower tip. The fact that only the shallower dike is detectable with InSAR is consistent with the intrusion of that dike at the level of neutral buoyancy which could correspond to a lithological discontinuity. Thus, at the level of neutral buoyancy, magma accumulates to make this part of the dike to be thicker than the deeper buoyant part [Ryan, 1994; Lister and Kerr, 1991; Taisne and Jaupart, 2009; Traversa et al., 2010]. Closure of the shallow dike is prevented by the positive magma overpressure.

\subsection{Relation between the depths of seismic swarms and dikes}

At Piton de la Fournaise volcano, all laterally injected dikes are located above the pre-eruptive seismic swarms, which is consistent with the observations that the upward propagation of magma generates seismicity [Battaglia and Bachèlery, 2003] and that the lateral injection of magma is nearly aseismic [Peltier et al., 2005]. This behavior may be associated with different ambient differential stresses within the edifice [Rubin and Gillard, 1998]. Below the level of neutral buoyancy ( $1000 \mathrm{~m}$ below the ground surface), ambient differential stresses could be large enough for dike propagation to induce shear failure of the rock matrix, whereas around the level of neutral buoyancy, where the shallow lateral dikes are emplaced, ambient differential stresses could be too small to induce micro-earthquakes. The cause of the low differential stresses could be the repeated dike intrusions. The intrusions are perpendicular to the minimum principal stress, thus increasing the stress normal to the dikes, eventually reducing the differential stresses and leading to an isotropic stress field [Chadwick and Dieterich, 1995]. This hypothesis is consistent with a previous study of the 1983-1984 Piton de la Fournaise eruption [Cayol and Cornet, 1998], which showed that, at the lateral dike level, stresses were close to isotropic.

\subsection{Localization of eruption to a circular vent}

Hours after their onset, eruptions at Piton de la Fournaise localize to a vent located at the lowest point of the eruptive fissures, from which magma continues to flow for a few days or more. Such localization has also been frequently observed on other basaltic volcanoes in Hawaii [Richter et al., 1970; Lockwood et al., 1987; Wolfe et al., 1987] and in Iceland [Björnsson et al., 1979; Thorarinsson et al., 1973]. This change in activity is indicative of a change in magma conduit shapes from dike-like to pipe-like, and is consistent with the change of mechanical processes associated with eruption evolution. Some small nonuniformity in the opening distribution along the eruptive fissure can cause localization of mechanical and thermal erosion [Ida, 1992] and preferred solidification, i.e., shutoff, of narrower parts [Bruce and Huppert, 1989, 1990]. The delivery of magma to the surface is thermally and mechanically more efficient in circular conduits than in dikes [Delaney and Pollard, 1981]. Using observed magma flow rates and plausible values for the driving pressure and viscosity, we estimate that the radius of the pipe for typical Piton de la Fournaise eruptions is of the order of one meter (Appendix B).

\subsection{Model of magma transfer in the Piton de la Fournaise volcano}

Based on the above considerations, we propose a model of magma transport for typical eruptions of the Piton de la Fournaise volcano. Firstly, overpressured magma in the magma reservoir located at sea level, or deeper, is injected subvertically, driven by the positive buoyancy of gasrich magma which segregated at the top of the reservoir [Vergniolle and Jaupart, 1990] and perhaps also by a gas pocket at the dike tip [Menand and Tait, 2001] (Figure 13a). The top of the dike may be so buoyant that it propagates subvertically until it erupts. However, the rest of 
(a)

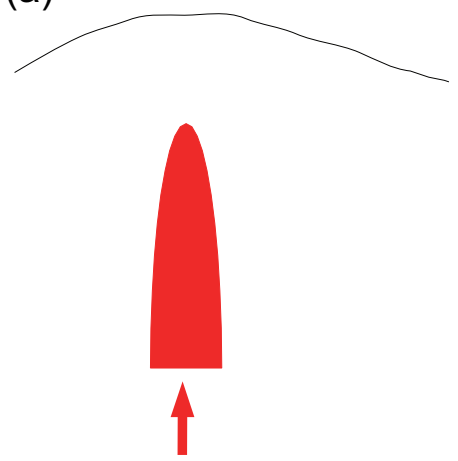

(b)

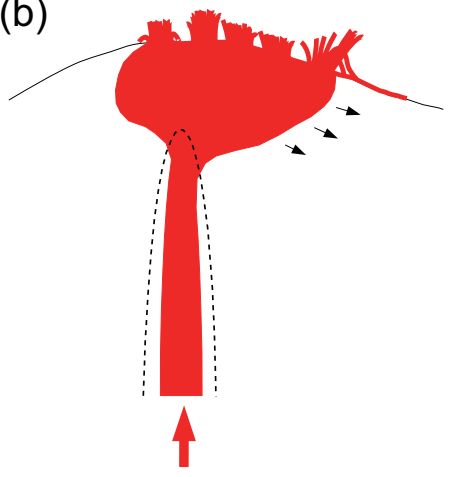

(c)

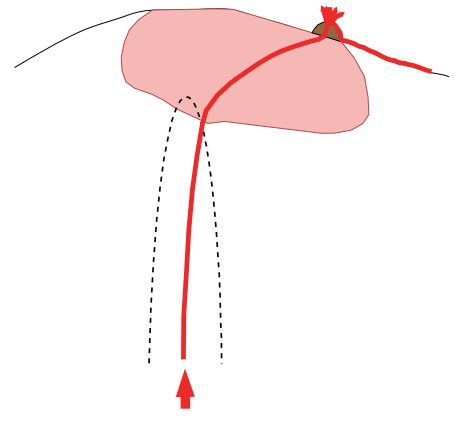

Figure 13. Proposed model of magma transfer and emplacement associated with typical eruptions in the central cone of Piton de la Fournaise volcano. (a) Overpressurized magma from the reservoir intrudes upward in a dike. The upward dike propagation can be driven by the buoyancy of the gas-rich magma and gas pocket at the tip of the dike. (b) At the eruption onset, the dike grows laterally in the downslope direction at depths shallower than $1000 \mathrm{~m}$. The lateral propagation results from magma reaching its neutral buoyancy level. As the overpressure in the reservoir decreases, the subvertical dike-type conduit starts to close. (c) Hours after the onset, because of magma cooling, the eruption localizes. A cylindrical conduit having a radius of about one meter is developed and the eruption continues for days to weeks. Magma solidification leaves a laterally-elongated dike rooted at depths of less than about $1000 \mathrm{~m}$.

the magma, which is more degassed, has its level of neutral buoyancy at a shallow depth (less than $1000 \mathrm{~m}$ ) so that the dikes grow laterally in the downslope direction (Figure 13b). As the overpressure of the reservoir decreases, the deep subvertical dike which had a positive buoyancy starts closing, while the laterally elongated part, located around the level of neutral buoyancy, remains open because of the overpressure profile which is maximized at this level. Hours after their onset, eruptions localize to a vent located at the lowest point of the eruptive fissures, from which magma continues to flow for a few days or more (Figure 13c).

\section{Conclusions}

InSAR data show that most of the dikes formed during the five 1998-2000 eruptions of the Piton de la Fournaise volcano are laterally elongated and rooted at, or shallower than, $1300 \mathrm{~m}$. Specifically, the bottom depth of our preferred models ranges from about $250 \mathrm{~m}$ (September 1999, except for the feeder part) to 1000-1300 m (June 2000) (Figure 11). Owing to the spatially dense InSAR data, the depths were generally well constrained with uncertainties smaller than $\pm 300 \mathrm{~m}$ for most of the cases. It should be noted, however, that the possibility of a deeper dike can not be ruled out for the March 1998 eruption. The total volume of the intruded dikes amounts to $17 \%$ of the total volume of lava emitted during the study period, indicating a predominantly exogenous growth of the volcano.

The laterally elongated dikes are located above the seismic swarms. This could be explained by low ambient differencial stresses [Rubin and Gillard, 1998] at the shallow depths where the lateral dikes are found, resulting from the numerous dike intrusions.

Tilt interpretations and visual observations indicate that magma is injected laterally in dikes from the summit area in the downslope direction. Pre-eruptive seismicity and our model calculations of tilt show that before the lateral dike injection, magma propagates vertically in dikes located below the volcano summit. This change in injection direction from vertical to lateral, as well as the lack of an interferometric signal associated with the deep vertical dike, indicate a level of neutral buoyancy located at less than $1000 \mathrm{~m}$ below the surface. Finally, magma flow localizes to a single vent which, from observed magma flow rates, is estimated to have a radius of the order of one meter.

Transport of magma into dikes at the onset of eruptions and in cylindrical pipes for sustained eruptions is consis- tent with mechanical processes, which indicate that the emplacement of dikes requires less work than the emplacement of cylindrical pipes, but that the delivery of magma to the surface is thermally and mechanically more efficient in cylindrical pipes than in dikes [Delaney and Pollard, 1981].

\section{Appendix A: Maximum Tilt Amplitudes for a Cylindrical Pipe and Dike}

The surface $(z=0)$ radial tilt change due to a vertical closed pipe located at a depth $c_{1}<z<c_{2}$ in an elastic half-space is given by [Bonaccorso and Davis, 1999, with correction by Segall [2010] for the case $\nu \neq 0.25$ ],

$$
\frac{\partial U_{3}}{\partial r}=\frac{a^{2} \Delta \operatorname{Pr}(1+\nu)}{2 E}\left[\frac{1}{R^{3}}\left\{2 \nu+1-\frac{3 r^{2}}{R^{2}}\right\}\right]_{c 1}^{c 2},
$$

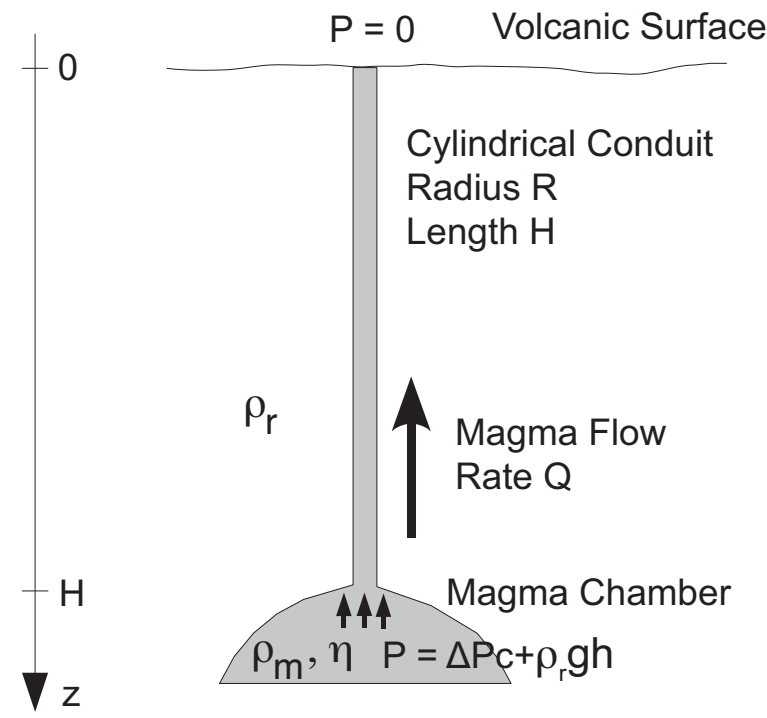

Figure 14. Model for laminar magma flow through a cylindrical conduit. Magma flow is driven by the pressure gradient between the reservoir and the ground. 
where $r$ is the radial distance, $a$ is the pipe radius, $\Delta P$ is the pressure change, $E$ is the Young's modulus, $\nu$ is Poisson's ratio, and $R=\left(r^{2}+z^{2}\right)^{1 / 2}$.

We assume that the pipe radius $a$ is ten meters, large enough to avoid solidification in the inter-eruption periods. A larger conduit would be inconsistent with observed flow rates (see Appendix B). From the vertical extension of the pre-eruptive micro-earthquake swarms, we assume parameters $c_{1}$ and $c_{2}$ in equation (A1) are $c_{1}=1000 \mathrm{~m}$ and $c_{2}=2000 \mathrm{~m}$.

We further compute the maximum possible overpressure $\Delta P$. Assuming stresses in the rock matrix are lithostatic, tensile failure of the rock matrix around the cylindrical conduit does not occur as long as [e.g. Jaeger et al., 2007]

$$
P<2 \rho_{r} g h+T_{0},
$$

where $P$ is the magma pressure, $\rho_{r}$ is the host rock density, $g$ is the acceleration of gravity, $h$ is the depth of the conduit point considered and $T_{0}$ is the rock tensile strength. Values for $T_{0}$ range from 0.5 to $5 \mathrm{MPa}$ [Hickman et al., 1985]. Thus, from equation (A2), the maximum overpressure sustainable by the rock matrix is

$$
\Delta P=P-\rho_{r} g h+T_{0} .
$$

At a depth of $1000 \mathrm{~m}$ below the ground surface, we find that the maximum overpressure sustainable in a cylindrical conduit is $25 \mathrm{MPa}$, assuming a rock density of $2400 \mathrm{~kg} / \mathrm{m}^{3}$ and a tensile strength of $1 \mathrm{MPa}$.

Further, taking $\mathrm{E}=5 \mathrm{GPa}$ and $\nu=0.25$, we obtain a maximum tilt change of $0.06 \mu \mathrm{rad}$ from equation A1. This is much smaller than observed tilt changes of tens of microradians.

In contrast, a mixed BEM computation for a rectangular dike having the same vertical extension, a reasonable width $500 \mathrm{~m}$, and an overpressure of $5 \mathrm{MPa}$ predicts a maximum tilt amplitude of $19 \mu \mathrm{rad}$, which is of the order of tilt changes detected at the onset of Piton de la Fournaise eruptions.

\section{Appendix B: Radius of Cylindrical Conduits During the Later Stages of Eruption}

Some time after eruptions localize to circular vents, lava output rates settle down and can be sustained for days to months, which allows one to consider the magma flow rate to be steady. In order to estimate the size of the conduit from observed output flow rates, we consider that magma flows from the source reservoir to the volcanic surface through a cylindrical pipe as suggested by the circular shape of the vent at the surface (Figure 14).

Assuming the magma is degassed, which is the case some time after the localization of an eruption, it can be treated as an incompressible viscous Newtonian fluid of viscosity $\eta$. We further consider that the pipe has no elastic interaction with the surrounding medium. Assuming the laminar flow is driven by the pressure gradient $d P / d z-\rho_{m} g$ along a pipe of radius $R$ and height $H$, the magma volumetric flow rate $Q$ can be written as [e.g. Jaupart, 2000]

$$
\begin{aligned}
Q & =-\frac{\pi R^{4}}{8 \eta}\left(\frac{d P}{d z}-\rho_{m} g\right) \\
& =-\frac{\pi R^{4}}{8 \eta}\left(\frac{P_{H}-P_{0}}{H}-\rho_{m} g\right),
\end{aligned}
$$

where $z$ is the depth, $P_{0}$ and $P_{H}$ are the magma pressures at the volcanic surface and the reservoir, respectively, and $\rho_{m}$ is the magma density. Further assuming that the magma pressure at the reservoir $P_{H}$ is the sum of lithostatic pressure $\rho_{r} g H$ and the overpressure $\Delta P_{c}$ and neglecting the atmospheric pressure $\left(P_{0}=0\right)$, the volumetric flow rate, equation
(B1), becomes

$$
Q=-\frac{\pi R^{4}}{8 \eta}\left(\frac{\Delta P_{c}}{H}+\left(\rho_{r}-\rho_{m}\right) g\right),
$$

Estimation of the conduit radius $R$ from the observed flow rate $Q$ can be considered robust because $R$ is to the fourth power:

$$
R=\left[\frac{-8 \eta Q}{\pi\left\{\frac{\Delta P_{c}}{H}+\left(\rho_{r}-\rho_{m}\right) g\right\}}\right]^{1 / 4}
$$

To compute the radius $R$, values for the other parameters are given as follows.

Viscosity, $\eta$ : The temperature of lavas emitted at the volcano ranges between $1100^{\circ} \mathrm{C}$ and $1160^{\circ} \mathrm{C}$. Villeneuve et al. [2008] made measurements of the viscosity of remelt lava of the March 1998 Piton de la Fournaise eruption. According to their empirical relationship, the viscosity is $327 \mathrm{Pas}$ and $104 \mathrm{Pas}$ for $1100^{\circ} \mathrm{C}$ and $1160^{\circ} \mathrm{C}$, respectively. Here, $\eta$ of $300 \mathrm{Pas}$ is assumed; variation in the predicted range does not make any significant difference because of the $\eta^{1 / 4}$ dependency that appears in equation (B3).

Height of the magma column, $H$ : The height is assumed to be the distance of the deepest hypocenters of the preeruption seismic swarms from the surface for the March 1998 eruption, i.e., $H=7500 \mathrm{~m}$. Here we hypothesize that all the studied eruptions share a common source magma reservoir. Although it may be more appropriate to assume a smaller height for subsequent eruptions, this height has little influence on the results.

Density contrasts, $\rho_{r}-\rho_{m}$ : The host rock density is assumed to be $2600 \mathrm{~kg} / \mathrm{m}^{3}$, a value intermediate between densities estimated at different elevations from borehole samples of the volcano [Rançon et al., 1989]. Because magma reservoirs are usually located at a level of neutral buoyancy [Ryan, 1987a, 1993, 1994], magma should be less dense than surrounding rocks below the reservoir level and denser than rocks above the reservoir. As an eruption proceeds, the content in exsolved gases diminishes leading to denser magmas. We assume that magma density increases from $2400 \mathrm{~kg} / \mathrm{m}^{3}$ at the beginning of eruptions to $2600 \mathrm{~kg} / \mathrm{m}^{3}$ at the end of eruptions, resulting in a density difference $\rho_{r}-\rho_{m}$ between the rock and magma that decreases from $200 \mathrm{~kg} / \mathrm{m}^{3}$ at the beginning of eruptions to zero at the end of eruptions.

Overpressure, $\Delta P_{c}$ : Two extreme values are tested for the overpressure: nearly zero $(0.1 \mathrm{MPa})$ and the maximum sustainable value against tensile failure of the rock matrix around a spherical magma reservoir $\left(\Delta P_{c}\right)_{\max }$. The tensile stress $\sigma_{t}$ at the wall of a spherical cavity in an infinite medium submitted to an internal pressure $p_{i n}$ and an external pressure $p_{\text {out }}$ is [Timoshenko and Goodier, 1970].

$$
\sigma_{t}=-\frac{3}{2} p_{\text {out }}+\frac{1}{2} p_{\text {in }}
$$

Rupture occurs when $\sigma_{t}$ reaches the tensile strength $T_{0}$, which has values ranging from 0.5 to $5 \mathrm{MPa}$ [Hickman et al., 1985]. Stresses in the rock matrix are assumed to be lithostatic $p_{\text {out }}=\rho_{r} g h$. Neglecting the atmospheric pressure, the reservoir pressure is $p_{i n}=\rho_{r} g h+\Delta P_{c}$. From equation (B4), we can calculate the maximum possible overpressure as

$$
\begin{aligned}
\left(\Delta P_{c}\right)_{\max } & =2\left(\rho_{r} g H+T_{0}\right) \\
& \sim 400 \mathrm{MPa} .
\end{aligned}
$$




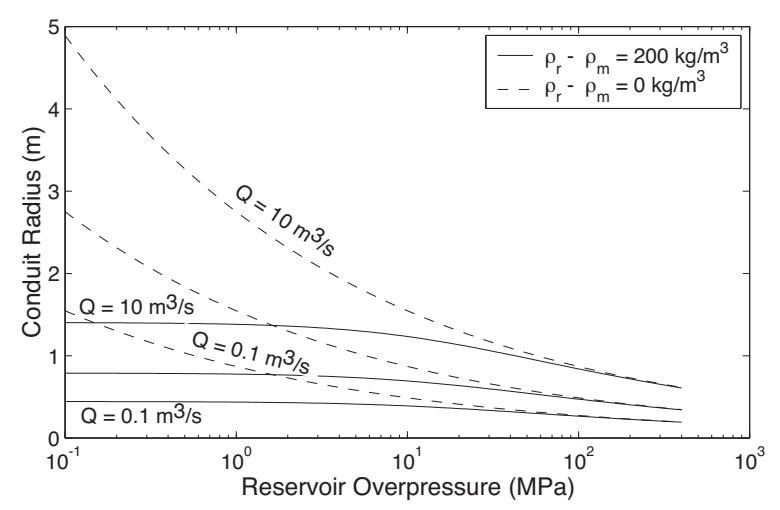

Figure 15. Cylindrical conduit radius as a function of the reservoir overpressure. Magma flow rates $Q$ of 0.1 , $1,10 \mathrm{~m}^{3} / \mathrm{s}$ are assumed for the two cases $\rho_{r}-\rho_{m}=$ $200 \mathrm{~kg} / \mathrm{m}^{3}$ (solid lines) and $\rho_{r}-\rho_{m}=0 \mathrm{~kg} / \mathrm{m}^{3}$ (dashed lines).

Flow rates, $Q$ : Lava flow rates were estimated as 15$30 \mathrm{~m}^{3} / \mathrm{s}$ three days after the onset of the March 1998 eruption [Villeneuve, 2000], on the northern eruption site. Until the end of the eruption, the lava output rate remained constant and at a low level (N. Villeneuve, personal communication, 2005). Mean lava output rates for the five eruptions between March 1998 and June 2000 are calculated to be 0.7 to $4.3 \mathrm{~m}^{3} / \mathrm{s}$ by dividing lava flow volumes by the eruption durations [Fukushima, 2005]. We therefore assume a range of magma flow rates between 0.1 and $10 \mathrm{~m}^{3} / \mathrm{s}$.

The evolution of the pipe radius $R$ as a function of the reservoir overpressure is estimated from equation (B3) for magma flow rates of $0.1,1$ and $10 \mathrm{~m}^{3} / \mathrm{s}$ and for the end members of the density contrasts $\rho_{r}-\rho_{m}$ (Figure 15). At an early stage, the magma flow rate is of the order of $10 \mathrm{~m}^{3} / \mathrm{s}$ and the density contrast can be as large as $200 \mathrm{~kg} / \mathrm{m}^{3}$. Figure 15 indicates that, at this stage, the radius of the conduit should be $0.7-1.4 \mathrm{~m}$. At a later stage, the flow rate decreases to a value of the order of $0.1 \mathrm{~m}^{3} / \mathrm{s}$ and the density contrast is close to zero because of degassing. In this case, the radius of the conduit is governed by the overpressure in the reservoir $\Delta P_{c}$ and has values of $0.2-1.5 \mathrm{~m}$. In conclusion, the radius of the conduit for the studied eruptions is of the order of one meter. Our estimation is comparable to Pedersen and Sigmundsson [2006] who estimated the radius of a magma conduit to be less than one meter at Eyjafjallajökull volcano in Iceland.

Acknowledgments. We thank Michael P. Ryan, Zhong Lu and an anonymous reviewers for thorough and thoughtful reviews. We are grateful to the Canadian Space Agency for the RADARSAT-1 data provided through ADRO2 253. We thank Jean-Luc Froger for suggestions on interferogram unwrapping and ground meshing, and Jean Battaglia and the Observatoire Volcanologique du Piton de la Fournaise for the seismicity data. An earlier version of this paper was reviewed by Benjamin van Wyk de Vries and Tim Druitt. We also thank Francesca van Wyk de Vries for English corrections before and after submission.

\section{References}

Acocella, V., M. Porreca, M. Neri, E. Massimi, and M. Mattei (2006), Propagation of dikes at Vesuvio (Italy) and the effect of Mt. Somma, Geophys. Res. Lett., 33, L08301, doi: 10.1029/2005GL025590.

Akaike, H. (1974), A new look at the statistical model identification, IEEE Trans. Automatic Control, AC-19, 716-723.

Amelung, F., and S. Day (2002), InSAR observations of the 1995 Fogo, Cape Verde, eruption: Implications for the effects of collapse events upon island volcanoes, Geophys. Res. Lett., 29, doi:10.1029/2001GL013760.
Amelung, F., S. Jónsson, H. Zebker, and P. Segall (2000), Widespread uplift and 'trapdoor' faulting on Galàpagos volcanoes observed with radar interferometry, Nature, 407, 993-996.

Aoki, Y., P. Segall, T. Kato, P. Cervelli, and S. Shimada (1999), Imaging magma transport during the 1997 seismic swarm off the Izu Peninsula, Japan, Science, 286, 927-930.

Augier, A., et al. (2008), The April 2007 eruption at Piton de la Fournaise, Réunion Island, imaged with ENVISAT-ASAR and ALOS-PALSAR data, USEReST workshop, Napoli, Italy.

Bachèlery, P. (1981), Le Piton de la Fournaise (Ile de la Réunion): Etude volcanologique, structurale et pétrologique, Ph.D. thesis, Université Clermont-Ferrand II.

Battaglia, J. (2001), Quantification sismique des phénomènes magmatiques sur le Piton de la Fournaise entre 1991 et 2000, Ph.D. thesis, Université Paris 7 Denis Diderot.

Battaglia, J., and P. Bachèlery (2003), Dynamic dyke propagation deduced from tilt variations preceding the March 9, 1998, eruption of the Piton de la Fournaise volcano, J. Volcanol. Geotherm. Res., 120, 289-310.

Battaglia, J., V. Ferrazzini, T. Staudacher, K. Aki, and J.-L. Cheminée (2005), Pre-eruptive migration of earthquakes at the Piton de la Fournaise volcano (Réunion Island), Geophys. J. Int., 161, 549-558.

Björnsson, A., G. Johnsen, S. Sigurdsson, G. Thorbergsson, and E. Tryggvason (1979), Rifting of the Plate Boundary in North Iceland 1975-1978, J. Geophys. Res., 84, 3029-3038.

Bonaccorso, A., and P. M. Davis (1999), Models of ground deformation from vertical volcanic conduits with application to eruptions of Mount St. Helens and Mount Etna, J. Geophys. Res., 104, 10,531-10,542.

Bonafede, M., and E. Rivalta (1999), On tensile cracks close to and across the interface between two welded elastic half-spaces, Geophys. J. Int., 138, 410-434.

Bonvalot, S., D. Remy, C. Deplus, M. Diament, and G. Gabalda (2008), Insights on the March 1998 eruption at Piton de la Fournaise volcano (La Réunion) from microgravity monitoring, J. Geophys. Res., 113, B05407, doi:10.1029/2007JB005084.

Brenguier, F., N. M. Shapiro, M. Campillo, A. Nercessian, and V. Ferrazzini (2007), 3-D surface wave tomography of the Piton de la Fournaise volcano using seismic noise correlations, Geophys. Res. Lett., 34, L02305, doi:10.1029/2006GL028586.

Brenner, S. L., and A. Gudmundsson (2004), Arrest and aperture variation of hydrofractures in layered reservoirs, Geological Society, London, Special Publications, 231, 117-128, doi: 10.1144/GSL.SP.2004.231.01.08.

Bruce, P. M., and H. E. Huppert (1989), Thermal control of basaltic fissure eruptions, Nature, 342, 665-667.

Bruce, P. M., and H. E. Huppert (1990), Solidification and melting along dikes by the laminar flow of basaltic magma, in Magma Transport and Storage, edited by M. P. Ryan, pp. 87-101, Wiley, Chichester, England.

Cayol, V., and F.-H. Cornet (1997), 3D mixed boundary elements for elastostatic deformation fields analysis, Int. J. Rock Mech. Min. Sci. Geomech. Abstr., 34, 275-287.

Cayol, V., and F.-H. Cornet (1998), Three-dimensional modeling of the 1983-1984 eruption at Piton de la Fournaise Volcano, Reunion Island, J. Geophys. Res., 103, 18,025-18,037.

Cervelli, P., P. Segall, F. Amelung, H. Garbeil, C. Meertens, S. Owen, A. Miklius, and M. Lisowski (2002), The 12 September 1999 Upper East Rift Zone dike intrusion at Kilauea Volcano, Hawaii, J. Geophys. Res., 107(B7), doi: 10.1029/2001JB000602.

Chadwick, W. W., and J. H. Dieterich (1995), Mechanical modeling of circumferential and radial dike intrusion on Galapagos volcanoes, J. Volcanol. Geotherm. Res., 66, 37-52.

Chen, C. W., and H. A. Zebker (2000), Network approaches to two-dimensional phase unwrapping: intractability and two new algorithms, J. Opt. Soc. Am., 17, 401-414.

Cheng, C. H., and D. H. Johnston (1981), Dynamic and static moduli, Geophys. Res. Lett., 8, 39-42.

Dahm, T. (2000), On the shape and velocity of fluid-filled fractures in the earth, Geophys. J. Int., 142, 181-192.

Delaney, P. T., and D. D. Pollard (1981), Deformation of host rocks and flow of magma during growth of minette dikes and breccia-bearing intrusions near Ship Rock, New Mexico, U. S. Geol. Surv. Prof. Paper, pp. 1202-1263. 
Froger, J.-L., Y. Fukushima, P. Briole, T. Staudacher, T. Souriot, and N. Villeneuve (2004), The deformation field of the August 2003 eruption at Piton de la Fournaise, Reunion Island, mapped by ASAR interferometry, Geophys. Res. Lett., 31, L14601, doi:10.1029/2004GL020479.

Fukushima, Y. (2005), Magma transfer at Piton de la Fournaise volcano from 3D modelling of radar interferometric data for 1998-2000, Ph.D. thesis, Université Clermont-Ferrand II, http://tel.archives-ouvertes.fr/tel-00011582.

Fukushima, Y., V. Cayol, and P. Durand (2005), Finding realistic dike models from interferometric synthetic aperture radar data: The February 2000 eruption at Piton de la Fournaise, $J$. Geophys. Res., 110, B03206, doi:10.1029/2004JB003268.

Gailler, L.-S., J.-F. Lénat, M. Lambert, G. Levieux, N. Villeneuve, and J.-L. Froger (2009), Gravity structure of Piton de la Fournaise volcano and inferred mass transfer during the 2007 crisis, J. Volcanol. Geotherm. Res., 184, 31-48, doi: 10.1016/j.jvolgeores.2009.01.024.

Hanssen, R. F. (2001), Radar Interferometry - Data Interpretation and Error Analysis, Kluwer Academic Publishers, Dordrecht, The Netherlands.

Hickman, S., J. Healy, and M. Zoback (1985), In situ stress, natural fracture distribution, and borehole elongation in the Auburn geothermal well, Auburn, New York, J. Geophys. Res. 90, 5497-5512.

Ida, Y. (1992), Width change of a planar magma path: implication for the evolution and style of volcanic eruptions, Phys. Earth Planet. Inter., 74, 127-138.

Jaeger, J. C., N. G. Cook, and R. W. Zimmerman (2007), Fundamentals of Rock Mechanics, fourth ed., Blackwell Publishing Ltd.

Jaupart, C. (2000), Magma ascent at shallow levels, in Encyclopedia of Volcanoes, edited by H. Sigurdsson, B. Houghton, S. R McNutt, H. Rymer, and J. Stix, pp. 237-245, Academic Press.

Jónsson, S., H. Zebker, P. Cervelli, P. Segall, H. Garbeil, P. Mouginis-Mark, and S. Rowland (1999), A shallow-dipping dike fed the 1995 flank eruption at Fernandina volcano, Galápagos, observed by satellite radar interferometry, Geophys. Res. Lett., 26, 1077-1080.

Jónsson, S., H. Zebker, P. Segall, and F. Amelung (2002), Fault slip distribution of the $1999 \mathrm{Mw} 7.1$ Hector Mine, California, earthquake, estimated from satellite radar and GPS measurements, Bull. Seismol. Soc. Am., 92, 1377-1389.

Klein, F. W., R. Y. Koyanagi, J. S. Nakata, and W. R. Tanigawa (1987), The seismicity of Kilauea's magma system, U. S. Geol. Surv. Prof. Paper, 1350, 1019-1185.

Labazuy, P. (1996), Recurrent landslides events on the submarine flank of Piton de la Fournaise volcano (Reunion Island), Geological Society, London, Special Publications, 110, 295-306.

Lénat, J.-F., P. Vincent, and P. Bachèlery (1989), The off-shore continuation of an active basaltic volcano: Piton de la Fournaise (Réunion Island, Indian Ocean); Structural and geomorphological interpretation from seabeam mapping, J. Volcanol. Geotherm. Res., 36, 1-36.

Lister, J. R., and R. C. Kerr (1991), Fluid-mechanical models of crack propagation and their application to magma transport in dykes, J. Geophys. Res., 96, 10,049-10,077.

Lockwood, J. P., J. J. Dvorak, T. T. English, R. Y. Koyanagi, A. T. Okamura, M. L. Summers, and W. R. Tanigawa (1987), Mauna Loa 1974-1984: A decade of intrusive and extrusive activity, U. S. Geol. Surv. Prof. Paper, 1350, 537-570.

Maillot, E. (1999), Les systèmes intrusifs des volcans boucliers oceaniques: Ile de la Réunion (Océan Indien), Ph.D. thesis, Université de la Réunion.

Massonnet, D., and K. L. Feigl (1998), Radar interferometry and its application to changes in the earth's surface, Rev. Geophys., $36,441-500$.

Menand, T., and S. R. Tait (2001), A phenomenological model for precursor volcanic eruptions, Nature, 411, 678-680.

Michon, L., T. Staudacher, V. Ferrazini, P. Bachèlery, and J. Marti (2007a), April 2007 collapse of Piton de la Fournaise: A new example of caldera formation, Geophys. Res. Lett., 34. L21301, doi:10.1029/2007GL031248.

Michon, L., F. Saint-Ange, P. Bachelery, N. Villeneuve, and T. Staudacher (2007b), Role of the structural inheritance of the oceanic lithosphere in the magmato-tectonic evolution of Piton de la Fournaise volcano (La Réunion Island), J. Geophys. Res., 112, B04205, doi:10.1029/2006JB004598.
Michon, L., V. Cayol, L. Letourneur, A. Peltier, N. Villeneuve, and T. Staudacher (2009), Edifice growth, deformation and rift zone development in basaltic setting: Insights from Piton de la Fournaise shield volcano (Réunion Island), J. Volcanol. Geotherm. Res., 184(1-2), 14-30, doi: 10.1016/j.jvolgeores.2008.11.002.

Morita, N., D. L. Whitfill, and H. A. Wahl (1988), Stress-intensity factor and fracture cross-sectional shape predictions from a three-dimensional model for hydraulically induced fractures, Journal of Petroleum Technology, 40, 1329-1342.

Morita, Y., S. Nakao, and Y. Hayashi (2006), A quantitative approach to the dike intrusion process inferred from a joint analysis of geodetic and seismological data for the 1998 earthquake swarm off the east coast of Izu Peninsula, central Japan, J. Geophys. Res., 111, B06208, doi:10.1029/2005JB003860.

Nercessian, A., A. Hirn, J.-C. Lepine, and M. Sapin (1996), Internal structure of Piton de la Fournaise volcano from seismic wave propagation and earthquake distribution, J. Volcanol. Geotherm. Res., 70, 123-143.

Okada, Y. (1985), Surface deformation due to shear and tensile faults in a half-space, Bull. Seismol. Soc. Am., 75, 1135-1154.

Owen, S., P. Segall, M. Lisowski, A. Miklius, M. Murray, M. Bevis, and J. Foster (2000), January 30, 1997 eruptive event on Kilauea Volcano, Hawaii, as monitored by continuous GPS, Geophys. Res. Lett., 27, 2757-2760.

Parfitt, E., and L. Wilson (2008), Fundamentals of Physical Volcanology, Blackwell Publishing Company, Victoria, Australia.

Pedersen, R., and F. Sigmundsson (2006), Temporal development of the 1999 intrusive episode in the Eyjafjallajökull volcano, Iceland, derived from InSAR images, Bulletin of Volcanology, $68,377-393$.

Peltier, A. (2007), Monitoring, modelling and evolution of magma injection processes at Piton de La Fournaise volcano (Reunion island), from a cross-analysis of deformation, geochemical and structural data, Ph.D. thesis, Univ. de La Réunion, http://tel.archives-ouvertes.fr/tel-00167895.

Peltier, A., V. Ferrazzini, T. Staudacher, and P. Bachèlery (2005), Imaging the dynamics of dyke propagation prior to the 2000 2003 flank eruptions at Piton de la Fournaise, Reunion Island, Geophys. Res. Lett., 32, L22302, doi:10.1029/2005GL023720.

Peltier, A., T. Staudacher, and Bachèlery (2007), Constraints on magma transfers and structures involved in the 2003 activity at Piton de La Fournaise from displacement data, J. Geophys. Res., 112, B03207, doi:10.1029/2006JB004379.

Peltier, A., V. Famin, P. Bachèlery, V. Cayol, Y. Fukushima, and T. Staudacher (2008), Cyclic magma storages and transfers at Piton de La Fournaise volcano (La Réunion hotspot) inferred from deformation and geochemical data, Earth Planet. Sci. Lett., 270, 180-188, doi:10.1016/j.epsl.2008.02.042.

Peltier, A., P. Bachèlery, and T. Staudacher (2009), Magma transport and storage at Piton de La Fournaise (La Réunion) between 1972 and 2007: A review of geophysical and geochemical data, J. Volcanol. Geotherm. Res., 184, 93-108, doi: 10.1016/j.jvolgeores.2008.12.008.

Poland, M. P., W. P. Moats, and J. H. Fink (2008), A model for radial dike emplacement in composite cones based on observations from Summer Coon volcano, Colorado, USA, Bull. Volcanol., 70, 861-875, doi:10.1007/s00445-007-0175-9.

Prôno, E., J. Battaglia, V. Monteiller, J.-L. Got, and V. Ferrazzini (2009), P-wave velocity structure of Piton de la Fournaise volcano deduced from seismic data recorded between 1996 and 1999, J. Volcanol. Geotherm. Res., 184, 49-62, doi: 10.1016/j.jvolgeores.2008.12.009.

Rançon, J.-P., P. Lerebour, and T. Auge (1989), The Grand-Brule exploration drilling: New data on the deep framework of the Piton de la Fournaise volcano. part 1: Lithostratigraphic units and volcanostructural implications, J. Volcanol. Geotherm. Res., 36, 113-127.

Richter, D. H., J. P. Eaton, K. J. Murata, W. A. Ault, and H. L. Krivoy (1970), Chronological narrative of the 1955-1960 eruption of Kilauea volcano, Hawaii, U. S. Geol. Surv. Prof. Paper, $537-E, 1-73$.

Rivalta, E., M. Böttinger, and T. Dahm (2005), Buoyancy-driven fracture ascent: Experiments in layered gelatine, J. Volcanol. Geotherm. Res., 144, 273-285.

Robson, G. R., and K. G. Barr (1964), The effect of stress on faulting and minor intrusions in the vicinity of a magma body, Bull. Volcanol., 27, 315-350. 
Rousset, D., A. Lesquer, A. Bonneville, and J.-F. Lénat (1989), Complete gravity study of Piton de la Fournaise volcano, Reunion Island, J. Volcanol. Geotherm. Res., 36, 37-52.

Rubin, A. M., and D. Gillard (1998), Dike-induced earthquakes: Theoretical considerations, J. Geophys. Res., 103, 10,01710,030 .

Ryan, M. P. (1987a), Neutral buoyancy and the mechanical evolution of magmatic systems, in Magmatic Processes: Physicochemical Principles: The Geochemical Society, Special Publication No. 1, Yoder Symposium, pp. 259-288.

Ryan, M. P. (1987b), Elasticity and contractancy of Hawaiian olivine tholeiite and its role in the stability and structural evolution of subcaldera magma reservoirs and rift systems, $U$. S. Geol. Surv. Prof. Paper, 1350, 1395-1447.

Ryan, M. P. (1993), Neutral buoyancy and the structure of midocean ridge magma reservoirs, J. Geophys. Res., 98, 22,32122,338 .

Ryan, M. P. (1994), Neutral buoyancy-controlled magma transport and storage in mid-ocean ridge magma reservoirs and their sheeted dike complex: a summary of basic relationships, in Magmatic Systems, edited by M. P. Ryan, pp. 97-135, Academic Press, San Diego, California, USA.

Sambridge, M. (1999a), Geophysical inversion with a neighbourhood algorithm - I. Searching a parameter space, Geophys. J. Int., 138, 479-494.

Sambridge, M. (1999b), Geophysical inversion with a neighbourhood algorithm - II. Appraising the ensemble, Geophys. J. Int., 138, 727-746.

Segall, P. (2010), Earthquake and Volcano Deformation, Princeton University Press.

Sigmundsson, F., P. Durand, and D. Massonnet (1999), Opening of an eruptive fissure and seaward displacement at Piton de la Fournaise volcano measured by RADARSAT satellite radar interferometry, Geophys. Res. Lett., 26, 533-536.

Staudacher, T., and J.-L. Cheminée (1999), Piton de la Fournaise, Bull. Global Volcanism Network, 24(7).

Staudacher, T., P. Bachèlery, M. P. Semet, and J.-L. Cheminée (1998), Piton de la Fournaise, Bull. Global Volcanism Network, 23(3), $2-4$.

Staudacher, T., N. Villeneuve, and J.-L. Cheminée (1999), Piton de la Fournaise, Bull. Global Volcanism Network, 24(9), 14-16.

Staudacher, T., N. Villeneuve, J.-L. Cheminée, K. Aki, J. Battaglia, P. Catherine, V. Ferrazzini, and P. Kowalski (2000), Piton de la Fournaise, Bull. Global Volcanism Network, 25(7), 14-16.

Taisne, B., and C. Jaupart (2009), Dike propagation through layered rocks, J. Geophys. Res., 114, B09203, doi 10.1029/2008JB006228.

Thorarinsson, S., S. Steinthórsson, T. Einarsson, H. Kristmannsdóttir, and N. Oskarsson (1973), The Eruption on Heimaey, Iceland, Nature, 241, 372-375.
Timoshenko, S. P., and J. N. Goodier (1970), Theory of Elasticity, 3rd ed., McGraw-Hill, Singapore.

Traversa, P., V. Pinel, and J. R. Grasso (2010), A constant influx model for dike propagation: Implications for magma reservoir dynamics, J. Geophys. Res., 115, B01201, doi: 10.1029/2009JB006559.

Vergniolle, S., and C. Jaupart (1990), Dynamics of degassing at Kilauea volcano, Hawaii, J. Geophys. Res., 95, 2793-2809.

Villeneuve, N. (2000), Apports multi-sources à une meilleure compréhension de la mise en place des coulées de lave et des risques associés au Piton de la Fournaise, Ph.D. thesis, Université de la Réunion.

Villeneuve, N., D. R. Neuville, P. Boivin, P. Bachèlery, and P. Richet (2008), Magma crystallization and viscosity: A study of molten basalts from the Piton de la Fournaise volcano (La Réunion island), Chemical Geology, 256, 242-251, doi:10.1016/j.chemgeo.2008.06.039.

Vlastélic, I., T. Staudacher, and M. Semet (2005), Rapid change of lava composition from 1998 to 2002 at Piton de la Fournaise (Réunion) inferred from $\mathrm{Pb}$ isotopes and trace elements: Evidence for variable crustal contamination, J. Petrol., 46, 79-107.

Walker, G. P. L. (1986), Koolau Dike Complex, Oahu: Intensity and origin of a sheeted-dike complex high in a Hawaiian volcanic edifice, Geology, 14, 310-313.

Weertman, J. (1971), Theory of water-filled crevasses in glaciers applied to vertical magma transport beneath oceanic ridges, J. Geophys. Res., 76, 1171-1183.

Wolfe, E. W., M. O. Garcia, D. B. Jackson, R. Y. Koyanagi, C. A. Neal, and A. T. Okamura (1987), The Puu Oo eruption of Kilauea Volcano, episodes 1???20, January 3, 1983, to June 8, 1984, U. S. Geol. Surv. Prof. Paper, 1350, 471-508.

Zeller, S. S., and D. D. Pollard (1992), Boundary conditions for rock fracture analysis using the boundary element method, $J$. Geophys. Res., 97, 1991-1997.

Y. Fukushima, Disaster Prevention Research Institute, Kyoto University, Uji, Kyoto, 611-0011, Japan, also at Department of Geophysics, Stanford University, 397 Panama Mall, Stanford, California, 94305. (yofukushima@rcep.dpri.kyoto-u.ac.jp)

V. Cayol, Laboratoire Magmas et Volcans, Univ. B. Pascal, CNRS UMR 6524, 5 rue Kessler 63038 Clermont-Ferrand, France. (valerie.cayol@opgc.univ-bpclermont.fr)

P. Durand, Centre National d'Etudes Spatiales, 18 Avenue E. Belin, 31055 Toulouse, France. (Philippe.Durand@cnes.fr)

D. Massonnet, Centre National d'Etudes Spatiales, 18 Avenue E. Belin, 31055 Toulouse, France. (Didier.Massonnet@cnes.fr) 


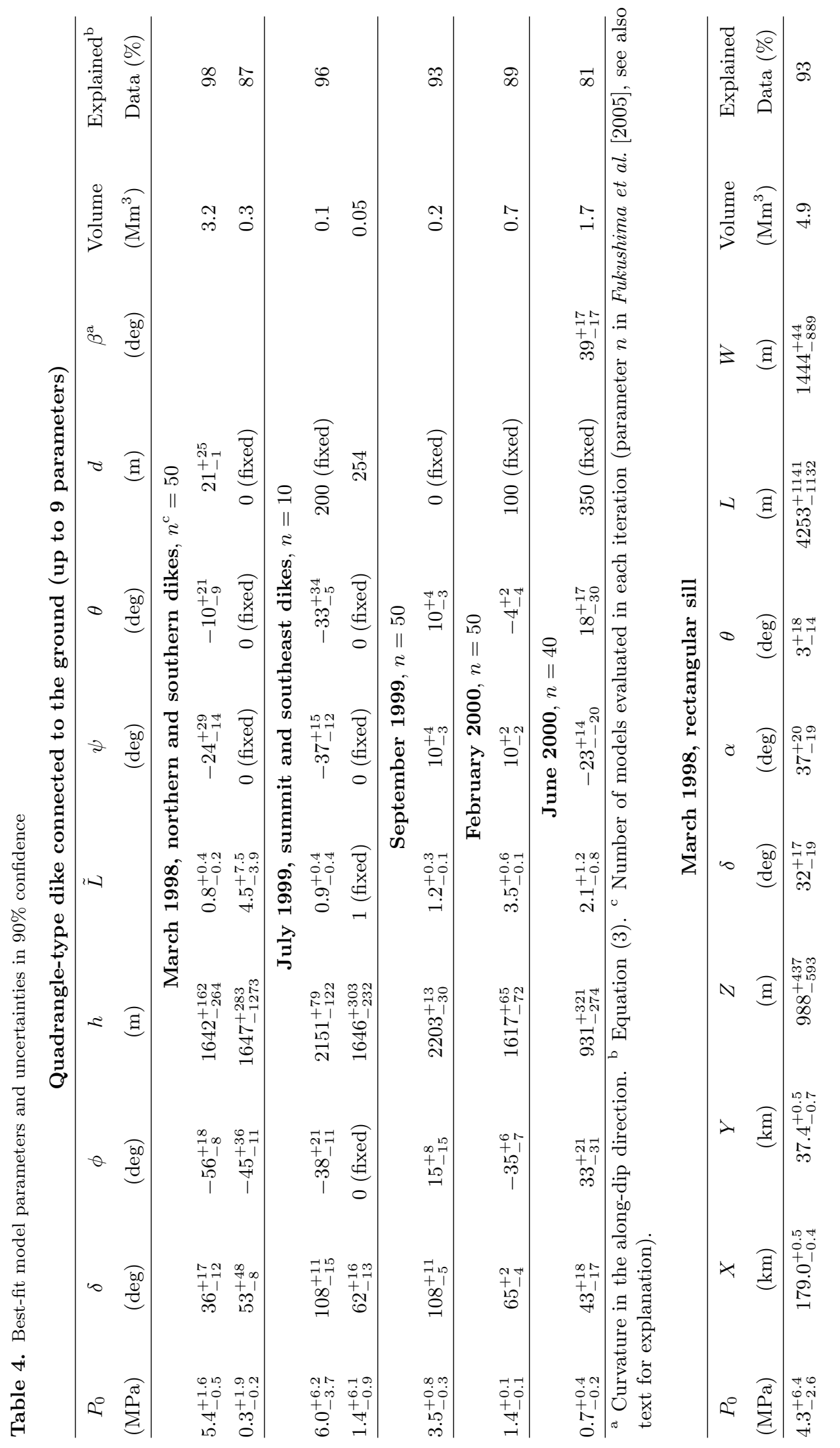


Table 5. AIC values of the intrusion models for the March 1998 eruption

\begin{tabular}{ll}
\hline Model & AIC \\
\hline Two dikes & -3303 \\
Two dikes + deep sill & -3032 \\
\hline
\end{tabular}

Table 6. AIC values of the intrusion models for the June 2000 eruption

\begin{tabular}{ll}
\hline Model & AIC \\
\hline Standard quadrangle & -4081 \\
Curved in along-dip direction & -4109 \\
Two dikes & -3906 \\
\hline
\end{tabular}

Table 7. Comparison of erupted and intruded volumes

\begin{tabular}{cccc}
\hline & $\begin{array}{c}\text { Erupted Volume } \\
\left(\mathrm{Mm}^{3}\right)\end{array}$ & $\begin{array}{c}\text { Intruded Volume } \\
\left(\mathrm{Mm}^{3}\right)\end{array}$ & $\begin{array}{c}\text { Total Volume } \\
\left(\mathrm{Mm}^{3}\right)\end{array}$ \\
\hline March 1998 & 45 & 3.5 & 48.5 \\
July 1999 & 1.8 & 0.2 & 2.0 \\
Sep. 1999 & 1.5 & 0.2 & 1.7 \\
Feb. 2000 & 7.0 & 0.7 & 7.7 \\
June 2000 & 10 & 1.8 & 11.8 \\
Total & 65.3 & 6.4 & 71.7 \\
\hline
\end{tabular}

